IMAGINARIOS SOCIALES FRENTE A LA CORPORALIDAD DE ESTUDIANTES DE GRADO DÉCIMO DEL COLEGIO LEONARDO POSADA PEDRAZA IED

\title{
LOCALIDAD BOSA
}

AUTOR

ESTEBAN RENNÉ GRANADOS PRIETO

\section{UNIVERSIDAD SANTO TOMÁS}

FACULTAD DE CULTURA FÍSICA, DEPORTE Y RECREACIÓN

MAESTRÍA EN ACTIVIDAD FÍSICA PARA LA SALUD

BOGOTÁ 
IMAGINARIOS SOCIALES FRENTE A LA CORPORALIDAD DE ESTUDIANTES DE GRADO DÉCIMO DEL COLEGIO LEONARDO POSADA PEDRAZA IED

\title{
LOCALIDAD BOSA
}

\author{
AUTOR \\ ESTEBAN RENNÉ GRANADOS PRIETO
}

PROYECTO DE GRADO MAESTRÍA

Elaborado como requisito para optar el título de

Magíster en Actividad Física para la Salud

\section{DIRECTOR}

\section{JULIO CÉSAR RUEDA CÁNTOR}

Magíster en Investigación Social Interdisciplinaria

UNIVERSIDAD SANTO TOMÁS

FACULTAD DE CULTURA FÍSICA, DEPORTE Y RECREACIÓN

MAESTRÍA EN ACTIVIDAD FÍSICA PARA LA SALUD

BOGOTÁ 


\section{Contenido}

INTRODUCCIÓN _...............................................................................................................9

PLANTEAMIENTO DEL PROBLEMA ............................................................................... 13

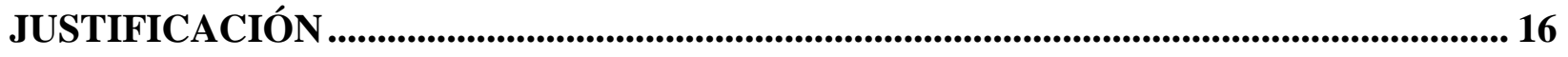

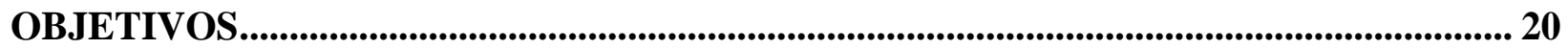

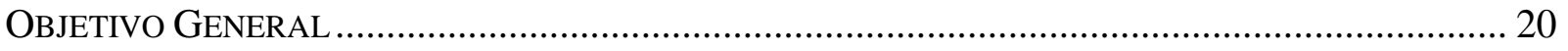

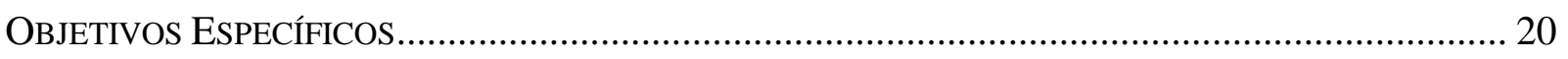

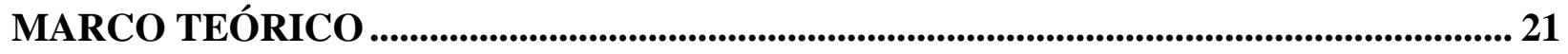

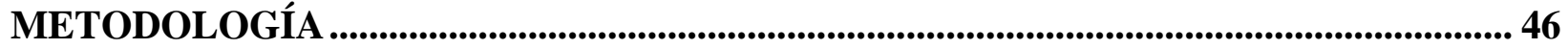

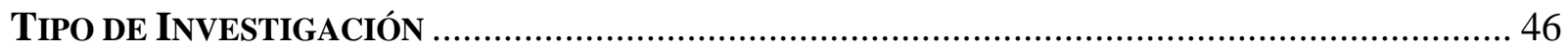

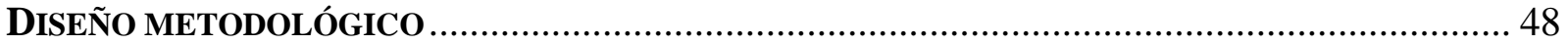

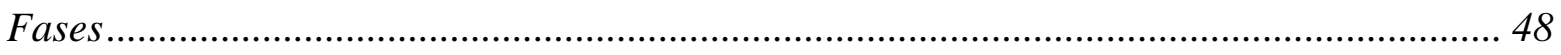

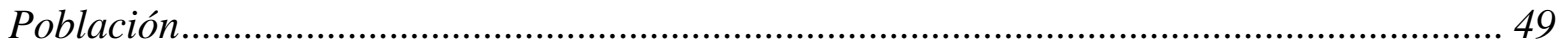

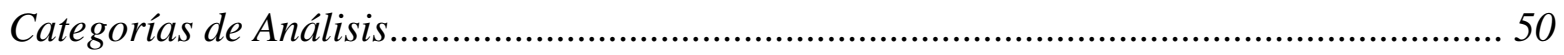

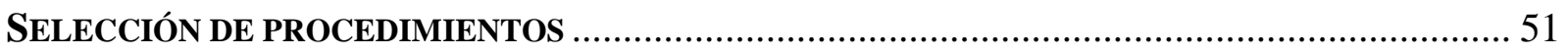

CONDICIONES DE RECOLECCIÓN DE LOS DATOS....................................................... 51

TÉCNICAS E INSTRUMENTOS DE RECOLECCIÓN DE INFORMACIÓN...................................... 52

ANÁLISIS E INTERPRETACIÓN DE DATOS ..................................................................... 54

ANÁliSIS E INTERPRETACIÓN DE DATOS PRIMERA FASE ................................................. 54

ANÁliSIS E INTERPRETACión de dATOS SEGUNDA FASE GRUPo FoCAL .......................... 58

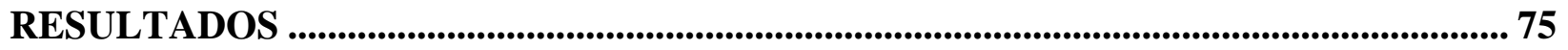

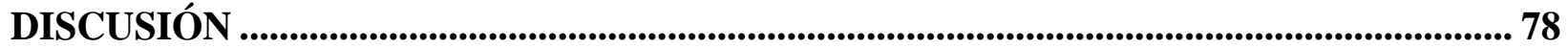

CONCLUSIONES, APORTES Y RECOMENDACIONES.................................................. 86

REFERENCIAS BIBIOGRÁFICAS ......................................................................................... 89

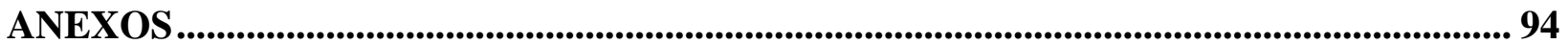


IMAGINARIOS SOCIALES FRENTE A LA CORPORALIDAD

\section{Lista de Tablas}

Tabla Nro. 1 Matriz Cuestionario de Corporalidad y Categorías

Tabla Nro. 2 Matriz Grupo Focal Tema Corporalidad 
IMAGINARIOS SOCIALES FRENTE A LA CORPORALIDAD

\section{Lista de Gráficos}

Grafico Nro. 1 Lectura de Necesidades

Gráfica Nro. 2 Resultados Test Fantástico

Grafica Nro. 3 Frecuencia Porcentaje Estilos de Vida 


\section{Lista de Figuras}

Figura 1. Diagrama Tiempos de ejecución de cada fase

Figura 2. Diagrama de relación entre técnicas e instrumentos. 


\section{Lista de Anexos}

Anexo A. Asentimiento Informado Estudiantes

Anexo B. Formato de Asentimiento Estudiantes

Anexo C. Formato de Asentimiento para Padres de Familia

Anexo D. Formulario de consentimiento Padres de Familia

Anexo E. Complemento Asentimiento Informado

Anexo F. Cuestionario Entrevista Corporalidad

Anexo G. Cuestionario de lectura de necesidades

Anexo G. Test de Autoevaluación Fantástico

Anexo H. Tabla de Frecuencia Absoluta

Anexo I. Tabla de Frecuencia Absoluta en Porcentaje 


\title{
IMAGINARIOS SOCIALES FRENTE A LA CORPORALIDAD DE ESTUDIANTES DE GRADO DECIMO DEL COLEGIO LEONARDO POSADA PEDRAZA I.E.D LOCALIDAD BOSA
}

\author{
Granados Prieto R.* \\ Universidad Santo Tomás
}

\section{Resumen}

La comprensión de los imaginarios sociales y las diferentes prácticas frente a la corporalidad de los estudiantes de grado décimo de un colegio público de Bogotá involucran el entorno escolar y el reconocimiento de las ideas que mayormente influyen en el pensamiento de los jóvenes. Comprender los imaginarios involucró para esta investigación la adopción de la etnometodología descriptiva. Las categorias de análisis fueron Imagen corporal IM, Cuerpo y Movimiento CM y Concepto Corporal C. Las técnicas e instrumentos para la recolección de datos se fundamentaron en la observación participante, la entrevista, el grupo focal, Test Fantástico y Encuestas de Calidad de Vida. La interpretación de los hallazgos a través de matrices y tablas de frecuencia absoluta y de porcentaje fundamentaron algunos lineamientos desde el área de Educación Física para fortalecer el autoestima de los jóvenes a partir del reconocimiento de la corporalidad, valoración de la belleza, de las características personales y corporales sin caer en un culto a su imagen externa, ni en el menosprecio de la misma. Las conclusiones permiten establecer la construcción de los imaginarios sociales a través de la presencia del otro y alteridad en cuanto a opiniones, expresiones y corporeidad.

Palabras clave: Cuerpo, Intersubjetividad, Corporalidad, Imaginarios Sociales, Educación Fisica. Adolescencia.

\begin{abstract}
The understanding of the social imaginaries and the different practices in front of the corporality of the students of degree tenth of a public school of Bogota involve the school environment and the recognition of the ideas that most influence in the thought of the young people. Understanding the imaginary involved for this research the adoption of descriptive ethnomethodology. The categories of analysis were Body image IM, Body and Movement CM and Body Concept $C$. The techniques and instruments for the data collection were based on the participant observation, the interview, the focus group, Fantastic Test and Quality of Life Surveys. The interpretation of the findings through matrices and tables of absolute frequency and percentage grounded some guidelines from the area of Physical Education to strengthen the selfesteem of the young from the recognition of the corporality, valuation of the beauty, of the personal characteristics And corporeal without falling into a cult of its external image, nor in the contempt of it. The conclusions allow to establish the construction of social imaginaries through the presence of the other and alterity in terms of opinions, expressions and corporeity.

Key words: Body, Intersubjectivity, Corporality, Social Imaginarios, Physical Education. Adolescence.

*Granados Prieto E. email: estebangranados@hotmail.es. Universidad Santo Tomás. Maestría en Actividad Física para la Salud.
\end{abstract}




\section{Introducción}

En las diferentes etapas de la vida se van adquiriendo y construyendo conocimientos dentro de un contexto determinado, que a su vez influyen en los conceptos, comportamientos y cuidados con respecto al cuerpo.

Al mismo tiempo las prácticas cotidianas y fenómenos que afectan a los sujetos son representados en un mundo simbólico comprendiendo éste como el conjunto de estructuras de pensamiento y marcos de referencia que originan un sistema de pensar común o lógico.

Los conceptos y significaciones del cuerpo se basan desde un marco de referencia simbólico dando lugar a conocimientos específicos que dan razón de las cosas y que por su complejidad o tradición son renuentes al cambio. Esto hace que las personas no cambien fácilmente sus creencias con respecto a la corporalidad por nuevos conocimientos que mejorarían el cuidado de la salud.

Bastante cierto es que generar cambios por un estilo de vida saludable resulta bastante dificultoso, pero también es cierto que comprender los riesgos y dificultades que malos hábitos como el sedentarismo, alcoholismo, consumo de drogas y mala alimentación pueden crear conciencia en la persona y dar motivación para emprender cambios por una vida saludable.

Cuando se le pregunta a los estudiantes acerca de hábitos cotidianos y cuidados que tienen con el cuerpo manifiestan un conocimiento general y cierta información al respecto que se maneja desde lo teórico pero casi nunca desde lo práctico. A pesar de conocer cuidados con respecto a la corporalidad no poseen el sentido lógico que supondría un cuidado real de sí 
IMAGINARIOS SOCIALES FRENTE A LA CORPORALIDAD

mismos, con frecuencia llevan a la práctica actividades nada saludables y de diversa índole, que van desde el consumo de sustancias psicoactivas y consumo regular de cigarrillo y alcohol hasta el sedentarismo prematuro y rutinas exigentes de ejercicio luego de haber trasnochado e ingerido bebidas alcohólicas y otras drogas.

Por otro lado los imaginarios han creado una especie de cultura que ha ido dejando huella por generaciones enteras mediante una serie de consecuencias para las funciones y prácticas del hombre y las funciones y el papel de la mujer. Inconscientemente el adolescente va construyendo su propia verdad e identidad en función del contexto, o sea de los estímulos sociales y familiares que recibe, y en función de valores, ideologías y creencias de su grupo de pertenencia. Va poco a poco transformando lo que sabe y construyendo su propio saber a través de la vivencia y su experiencia en el mundo social.

Es necesario mencionar también la perspectiva de género como un factor importante que evidencia diferencias de pensamiento reflejadas en ideas, conceptos y actuaciones de ambos géneros con respecto al tema de la corporalidad. Mientras que el género masculino, en general presenta interés en mejorar su capacidad física para lograr mejor resistencia y fuerza; el género femenino busca pertenecer al estereotipo social más llamativo. En esa medida el interés se enfoca en lo estético, y esto puede dar lugar a reemplazar el ejercicio, los buenos hábitos y la actividad física, por trucos, fajas, y posteriormente en algunos casos cirugías riesgosas.

Esta actitud se ve reforzada por los poderosos medios de comunicación, sobre todos los que presentan y venden la imagen que ponen de modelos corporales perfectos. Pero, ¿cómo se sienten los adolescentes que no cumplen con estos estereotipos? 
IMAGINARIOS SOCIALES FRENTE A LA CORPORALIDAD

Este trabajo trata de analizar algunos de los imaginarios sociales con respecto a la corporalidad que consideran estudiantes de grado décimo del colegio LEONARDO POSADA PEDRAZA I.E.D Jornada Tarde, ubicado en la localidad de Bosa en Bogotá. Para llevar a cabo este análisis se realizó el abordaje con profundidad de los conceptos: imaginarios sociales, corporalidad y adolescencia.

En concordancia, el género femenino refiere de los cuidados de la vida diaria mayor preocupación por garantizar este tipo de cuidados principalmente los relacionados con la alimentación, el cuidado del cuerpo, el embellecimiento del mismo y todos aquellos necesarios para proteger y mantener el cuerpo en un entorno de belleza.

El primer concepto referenciado en el marco teórico fue el de la corporalidad; sus concepciones a lo largo de la historia y en distintos lugares del mundo, conceptos y definiciones de autores reconocidos por su amplio estudio y conocimiento del tema. Posteriormente se analizaron distintas nociones y conceptos que tienen relación con los imaginarios sociales y por último la adolescencia con algunas de sus características principales. En el marco metodológico se relatan y aclaran los instrumentos empleados en la organización y recolección de la información. Con el fin de obtener información relevante sobre los usos sociales del cuerpo y dado que estos usos en cierta manera se perciben como una forma de lenguaje, de discurso típico de cada sociedad o grupo social y constituyen modalidades de pensamiento orientado hacia la comunicación y la comprensión se decidió emplear el instrumento de la entrevista semiestructurada. Estas entrevistas aplicadas a los grupos focales permitieron explorar los imaginarios sobre el concepto de cuerpo y desde la perspectiva del adolescente, ya que se adoptó 
IMAGINARIOS SOCIALES FRENTE A LA CORPORALIDAD

la noción de uso social del cuerpo como aquella que nos sitúa en el punto donde se articula lo psicológico con lo social.

El presente trabajo aborda, por un lado, la temática de los imaginarios sociales del cuerpo, en especial en el campo de la educación física y por el otro, intenta relacionar los datos obtenidos al aplicar las entrevistas con el marco teórico.

Finalmente en el capítulo de anexos podemos ver con más detalle y claridad algunos de los soportes obtenidos, resultado del proceso investigativo llevado a cabo. 


\section{Planteamiento del problema}

La localidad de Bosa es una de las más grandes de la ciudad de Bogotá y cuenta con varios espacios como parques, coliseos, entre otros escenarios deportivos muy propicios en cuanto a favorecer y fomentar una cultura del cuidado de la corporalidad, mediante la actividad física, en sus habitantes y alrededores; sin embargo, es limitado el número de personas que utilizan estos espacios con ese fin.

Desde el ámbito estudiantil se refleja en los estudiantes que la percepción de sí mismos como grande o pequeño, fuerte o débil, gordo o delgado, feo o bonito, influye en la manera como ellos se relacionan con los demás. En la clase de Educación Física un buen ejemplo son los estudiantes tímidos, que llenos de complejos o temores son incapaces de quitarse la chaqueta o usar pantaloneta ya que su cuerpo se expone a la mirada de los demás compañeros, con lo que su conducta tiende a ser más de inhibición que de participación.

Por otro lado están aquellas niñas que desearían estar "en el cuerpo de otra", tal vez obedeciendo inconscientemente a la segregación y exclusión grupal de la que son víctimas tan solo por el hecho de no ser observadas como personas sino como objetos. Se percibe de igual forma dificultades en la autoestima y dificultades manifiestas en el seno familiar cuyos efectos provocan cuidado inadecuado del cuepo expresado en Anorexia y Bulimia (2011):

(...) “sumado a débiles procesos de socialización familiar y de baja autoestima, hace que se sientan menos inseguros refugiándose en el cuidado externo del cuerpo, sacrificando su salud y llegando hasta las últimas consecuencias en conductas inadecuadas y en caso arriesgadas" (p.8) 
IMAGINARIOS SOCIALES FRENTE A LA CORPORALIDAD

En cuanto a la apariencia física la mayoría de estudiantes siguen patrones conductuales con respecto a los adornos en su corporalidad como lo son: el uso accesorios, pearcings, extensiones, tatuajes, tinturas y cortes de cabello, entre otros, según lo que esté de moda en su contexto y entorno habitual.

Estas conductas pueden afectar la autenticidad o forma de ser ya que a partir de la aprobación o desaprobación grupal el adolescente cambia su presentación de sí mismo ante su familia, sociedad, y su mundo. En cierta forma deja de pensar y actuar para sí mismo, pues lo que le interesa en el momento es sentirse aceptado por los otros y en ese afán de aceptación se constriñe su capacidad de opinar, elegir y decidir afectando su despliegue personal. Dadas estas circunstancias no cabe duda de que el adolescente también en este caso puede arriesgar su integridad y por ende su salud.

Otro rasgo de inseguridad y malestar se evidencia en estudiantes que se resignan con sentimiento de rabia y en ocasiones de tristeza a ser los señalados cada vez que el pesado del grupo quiera hacer bullying, y lejos de hacer algo por mitigar lo que sucede se encierran en sí mismos y exageran su inconformismo descuidando seriamente su imagen corporal externa.

Ante esta problemática de los estudiantes expresada también en diversas formas de conducta, como apatía al ejercicio, descuido en su nutrición, comodidad en su sedentarismo y de otro lado exagerado interés por la imagen corporal, resulta necesario retomar aquellos estudios que nos acerquen a la comprensión de lo que constituye el imaginario del adolescente, para que de esta manera se logren proponer directrices que permitan el abatimiento de dificultades en la inserción social por las que cursan los grupos de esta edad. Por lo anterior, la pregunta que direccionó el presente trabajo fue: ¿Cuáles son los imaginarios sociales que frente a la 
IMAGINARIOS SOCIALES FRENTE A LA CORPORALIDAD

corporalidad tienen estudiantes de grado décimo del colegio Leonardo Posada Pedraza I.E.D, en

la Localidad de Bosa? 


\section{Justificación}

La adolescencia es una etapa de grandes cambios físicos, psicológicos, sociales y comportamentales. En este período el adolescente está en busca de su personalidad, formación social y adquisición de conocimientos. Dentro de estos cambios es importante enfocar al joven hacia un estilo de vida saludable en el que se involucre también su grupo familiar favoreciendo la calidad de vida a través de la actividad física y un amplio despliegue de la corporalidad.

Pensando en el desarrollo completo y sano de una persona lo más pertinente es que desde el colegio se incluya en la educación la resignificación del ser humano. Para ello se requiere de una educación que asuma al ser; sin negar su esencia, es decir, comprendiendo en él desde la capacidad de soñar y tener emociones hasta la posibilidad de ser proyectados hacia el futuro con múltiples posibilidades. Existe una alta probabilidad en el colegio de brindar herramientas efectivas para iniciar y fortalecer ese sentido de valor real por la vida, de reconocerse como personas humanas y multidimensionales.

En este orden de ideas que el adolescente asuma y reconozca ampliamente su corporalidad es una labor que corresponde a todas las áreas del conocimiento; y más aún al área de Educación Física.

La Educación física promueve de manera natural estilos de vida saludables mediante diversas prácticas sin caer en el excesivo rigor deportivo pero si refiriéndose al disfrute del movimiento ya sea en algún deporte o disciplina similar, o bien en un juego o tal vez un ejercicio en particular. 
IMAGINARIOS SOCIALES FRENTE A LA CORPORALIDAD

Procurar que mediante la regularidad de la actividad física se reconozcan y aprendan aspectos importantes y vitales para promover una buena salud, un equilibrado estado emocional y una sana autoestima entre otros, hace parte de una educación significativa pero para ello es necesario que el licendiado en Educación Física comprenda y reconozca el sentir corporal de sus estudiantes y todo su bagaje cultural.

A través de la actividad física se pretende favorecer al estudiante adolescente desde diversos aspectos que tienen relación con la conciencia del ser en cuanto a su corporalidad. Proporcionar elementos útiles y versátiles que permitan replantearse a sí mismo y pensar en la actual sociedad de la que hace parte para que de la misma manera sea capaz de participar, desenvolverse adecuadamente y responder a las exigencias de la vida actual, tanto en el trabajo como en el ocio.

En la actualidad, estar en forma es un aspecto relevante para la sociedad, este concepto impulsa industrias lucrativas y ambiciosas. Por otro lado en muchos ámbitos la falta de forma física puede representar cierto estatus y hasta convertirse en algún tipo de segregación social.

La desmitificación hacia nuevas imágenes de cuerpos tiene mucha relación con las distintas maneras como se concibe la Educación Física, de tal manera es conveniente que el adolescente conozca la complejidad de la corporalidad y como en ella están incluidas muchas dimensiones que son prácticamente la esencia del ser en sí. Así, por ejemplo están presentes los grandes e inherentes rasgos culturales y costumbres, incluidas aquellas limitaciones sociales presentes en la casa, la escuela, el trabajo y en el deporte.

De acuerdo con lo anterior, conocer las creencias, pensamientos y usos sociales del cuerpo que vivencian los jóvenes en esta actual sociedad consumista, de ventas y moda para 
IMAGINARIOS SOCIALES FRENTE A LA CORPORALIDAD

complejizar sobre el significado de los imaginarios sociales constituyeron la base de esta investigación.

A la vez, la identificación y comprensión de los imaginarios permitieron establecer algunos los lineamientos que se encaminaron a motivar y rescatar la identidad que cada persona posee; propiciar el reconocimiento de la singularidad para respetar y aceptar las diferencias personales. Reconocer que cada persona merece vivir y ser libre de estereotipos impuestos por una sociedad de consumo ilimitado. Es necesario pensar en una rehumanización de la persona y dejar de cosificarnos y calificarnos tratándonos como si se tratase de una máquina que se debe explotar hasta el límite.

Por lo anterior es necesario rescatar y adoptar una visión humanista desde el colegio, pues deben emprenderse acciones por y con respecto a la dignificación del ser humano y a los valores que como tal tiene derecho a sentir.

Deci, Vallerand, Pelletier y Ryan (1991) afirman que el colegio representa la primera influencia social que tiene un enorme impacto sobre el rumbo que las personas viven y sucesivamente lo es la sociedad. Es así como, el colegio toma un rol fundamental al desarrollo del individuo por medio de variadas experiencias que influyen en su personalidad, formación social y adquisición de conocimientos.

A través de este proyecto se pretendía descubrir o conocer más acerca de los imaginarios que el estudiante tiene con respecto a su corporalidad con el fin de generar cambios en diversos aspectos fundamentales y característicos de la adolescencia y que tienen sentido en cuanto a la conciencia de la corporalidad en el ser. 
IMAGINARIOS SOCIALES FRENTE A LA CORPORALIDAD

Los estudiantes de grado décimo del colegio Leonardo Posada Pedraza se encuentran en una edad importante para la toma de decisiones, pero al mismo tiempo afloran los intereses por encontrar en ellos mismos y a través del movimiento una gran motivación para forjar su personalidad.

Este proyecto fue útil como instrumento para que el estudiante tomara conciencia de la responsabilidad que tiene con sí mismo, su salud y calidad de vida a través del despliegue de su corporalidad y mediante la actividad física. 


\section{Objetivos}

\section{Objetivo General}

Comprender los imaginarios sociales frente a la corporalidad de los estudiantes de grado décimo del Colegio Leonardo Posada Pedraza I.E.D.

\section{Objetivos Específicos}

Caracterizar los usos corporales que predominan en los adolescentes con respecto a los imaginarios de su corporalidad.

Identificar los factores que influyen en los imaginarios de los adolescentes en cuanto a corporalidad y bienestar.

Proponer lineamientos que posibiliten la creación de procesos de acompañamiento e intervención que permitan construir resignificaciones frente a la corporalidad en jóvenes escolares. 


\section{Marco Teórico}

Los imaginarios sociales que construyen y deconstruyen la realidad de los adolescentes frente al tema de la corporalidad expresa de forma persistente la interpretación del pensamiento de cada quién o de determinado grupo social.

Cada uno de los núcleos temáticos de este trabajo de investigación se concatenan para dar una mayor comprensión a la caracterización de dichos imaginarios. En este sentido, las aproximaciones teóricas surgen de tres afirmaciones que se presentan a continuación.

\section{Los imaginarios sociales construyen e interpretan realidades humanas}

El carácter colectivo del concepto de imaginario supone una interpretación desde el aporte de Cornelius Castoriadis (1997) quién afirma que éste "es la configuración de significaciones históricas". Cada individuo gracias a las significaciones identifican su propio mundo y el de los otros. Sin embargo, la comprensión de los imaginarios sociales surge de las significaciones. Cornelius Castoriadis (1997) afirma que las significaciones son imaginarias y sociales. Estas dos características consideran elementos racionales y reales mediados por la capacidad de creación de cada individuo. Ahora bien, éstas constituyen a la vez un bien instituido, participativo de entes anónimos y generales, el cual proporciona participación y alteridad, es decir, los imaginarios se establecen en la medida que se reconozca la existencia del otro. (López Calderón, G. y León Ramírez A.2013. p.23)

En este orden de ideas, las características de los imaginarios sociales propuestos por Cornelius Castoriadis (1997) permitieron consolidar la mirada teórica de esta investigación al 
IMAGINARIOS SOCIALES FRENTE A LA CORPORALIDAD

tomarlo como una creación histórica referenciada en el tiempo y espacio de los jóvenes. Esta característica de los imaginarios sociales permiten la interpretación desde dos miradas: lo instituido y lo instituyente.

La primera hace referencia al reconocimiento y existencia de significaciones colectivas y la segunda a la capacidad de transformación de los imaginarios. Estos dos aspectos direccionan la investigación hacia la propuesta de algunos lineamientos que faciliten la comprensión de los imaginarios de la corporalidad de los jóvenes. Cornelius Castoriadis (1997) afirma que el imaginario social dimensiona desde la capacidad de "instituir, transformar y de conferirle sentido a los aconteceres” (López Calderón, G. y León Ramírez A.2013. p. 24).

Por otra parte, el Grupo de Motricidad Humana y Mundos Simbólicos (2005) conceptualiza el imaginario con la representación, la imagen, la realidad de lo simbólico considerándose como muy cercano a ella o incluso asumiéndose como sinónimos; pero con todo ello, ninguna de estas expresiones llena su total sentido toda vez que, en realidad el imaginario se va constituyendo como un interjuego entre cada una de estas, en un marco histórico y social de los sujetos. (p.50)

En consecuencia, se puede hablar de elementos que configuran la noción de imaginario, no obstante, es en la relación, interconexión - unión que emerge el concepto de imaginario.

Continuando con la reflexión, el Grupo Motricidad Humana y Mundos Simbólicos (2005) señala:

“Lo imaginario es entonces una construcción más que subjetiva, intersubjetiva e intrasubjetiva... es más que la subjetivación de la imagen, puesto que ésta se relaciona con la representación y aquel con el sentido otorgado a toda una vida de formas, sentimientos, percepciones, motivos para las acciones e interacciones, necesidades y deseos." (p.50) 
IMAGINARIOS SOCIALES FRENTE A LA CORPORALIDAD

Consecuentemente con lo expuesto, los seres humanos logran representar la realidad en imágenes, no obstante, estas imágenes se cargan de sentido a través de las múltiples relaciones que los seres humanos despliegan en la vida, de allí entonces comienza a emerger y a construirse el mundo de lo imaginario.

Lo imaginario está constituido en un proceso que requiere una cierta enajenación estructural; es el reino de la identificación espacial que inicia en el estadio del espejo y es instrumental en el desarrollo de la agencia psíquica. Es en este proceso de formación que el sujeto puede identificar su imagen como el 'yo', diferenciado del otro. Lo que se designa como 'yo' es formado a través de lo que es el otro —en otras palabras, de la imagen en el espejo-. Es la forma primitiva de pensamiento simbólico (Pedemonte, 2008, p.1).

Teniendo en cuenta la corporalidad, en términos imaginarios, el cuerpo se ha instituido o instaurado en las sociedades de acuerdo a las características propias de estas, a sus contextos, sus costumbres, sus prácticas culturales, sus modos de ser y de vivir en el mundo de la vida cotidiana. Los jóvenes expresan sus imaginarios desde la imagen que poseen de su cuerpo y el de los demás, en principio prevalece lo externo y luego se profundiza en lo interno tales como muestras de afecto, actitudes, expresiones no verbales y escritas entre otras manifestaciones.

Los imaginarios sociales respecto a la corporalidad de los jóvenes involucra el ámbito escolar, así como los discursos académicos que surgen de la pedagogía. En concordancia Schutz (2008) y Shotter (2001) exhaltan la importancia de generar espacios de formación holística e íntegra que permitan al sujeto reconocer su cuerpo y el del otro la dimensión física, 
IMAGINARIOS SOCIALES FRENTE A LA CORPORALIDAD

motriz y biológica sin desestimar lo expresivo, las formas de comunicación, el sentir particular y general, lo creativo así como los diferentes componentes que generan la corporalidad en cada sujeto.

Pedemonte (2008) afirma que lo imaginario es un proceso con “cierta enajenación estructural”, alcanza su expresión en el plano espacial con el recurrente del espejo y es imprescindible en la psiquis de cada quién. (p.1)

Como complemento a la consolidación de los imaginarios sociales en el trabajo denominado La corporeidad: un imaginario que se instituye, constituye y reconstituye en el mundo de la vida cotidiana (2010) los autores Ponty y Sergio afirman que solamente la aparición de las praxis como resultado de la reflexión y profundización de los discursos de las personas abren espacio a los imaginarios sociales fundamentados en las realidades y vivencias humanas. Pero solo se dan en la medida que se generen discusiones y verbalizaciones por medio del uso del lenguaje. En esta construcción la dignificación y valor del cuerpo surgen de y para la sociedad de forma transversal en cuanto a los sentimientos, deseos, pensamientos y acciones del ser y su entorno.

López Calderón, G. y León Ramírez A.(2013) afirman que los imaginarios surgen de la simbolización, Castoriades (1998) señala que "lo imaginario debe utilizar lo simbólico, no sólo para expresarse, lo cual es evidente, sino para existir, para pasar de lo virtual a cualquier otra cosa más" (p.65)

En este orden de ideas, comprender a los jóvenes desde sus realidades puede ser a través de la observación de los imaginarios sociales y lo que los rodea facilitarán la construcción de 
IMAGINARIOS SOCIALES FRENTE A LA CORPORALIDAD

los mismos con sus transformaciones y aportaciones subjetivas, solo él que participa en una realidad es dueño de intervenirla, comprenderla y significar, en este caso, la corporalidad.

Al respecto, Juan Luis Pintos (2000) afirma que los imaginarios sociales son "aquellos esquemas construidos socialmente que nos permiten percibir, explicar e intervenir en lo que cada sistema social se considere como realidad” (p. 20). En esta construcción no solo participa el sujeto; las instituciones y el mismo Estado suman realidades y determinan formas de actuar y pensar para darle sentido.

Los imaginarios entonces, permitirán una distinción de la realidad y al mismo tiempo el reconocimiento de múltiples verdades. En el campo específico los imaginarios de los adolescentes frente a la corporalidad, se podría decir que de acuerdo con su práctica e inmersión en la clase de educación física, cada uno crea conceptos ya sea positivos o negativos paralelos a su desempeño en las actividades que se proponen en la clase.

La creación constante conlleva un mundo nuevo imaginado a partir de cada una de las significaciones que los individuos han hecho de la realidad, de esta forma surgen nuevos sujetos, nuevas ideas, que difieren de lo instituido en la sociedad. Lo anterior, justifica el abordaje de los imaginarios en jóvenes respecto a su corporalidad en un escenario escolar cuyas interacciones facilitan construcciones y deconstrucciones, discusiones, encuentros con el otro, valoración de actitudes e identificación de valores sobre el cuerpo, la belleza y la salud mezclados con el ideal de la expresión humana a través de la corporalidad.

Instituir una realidad aceptada por muchos de los jóvenes frente al tema de la corporalidad representa espacios de discusión y problematización entre lo que es real y lo 
IMAGINARIOS SOCIALES FRENTE A LA CORPORALIDAD

imaginario. Los jóvenes se convierten en eslabones pertenecientes a la sociedad en concordancia al deseo de transformarla mediante la capacidad creativa y de lectura.

Albaitero (2002) sustenta que “Las instituciones marcan una dirección de sentido que los sujetos viven como normas, valores, lenguaje, imágenes y formas; así, las instituciones no son sólo herramientas de creación sino formadores de subjetividades" (p. 23). La escuela como formadora de subjetividades supone una labor directa frente al conocimiento del cuerpo y el reconocimiento de las dimensiones para la expresión y creatividad humanas. Lograrlo requiere sin discusión uan interpretación y comprensión de la corporalidad de los jóvenes tal como lo afirma Cornelius Castoriadis.

Existen condiciones sociales, históricas y psíquicas en el ser humano las cuales se relacionan directamente con las problemáticas existentes. Cornelius Castoriadis afirma que “una interpretación real de los problemas sociales contemporáneos debe partir de la realidad misma del ser humano". El conocimiento de lo que le sucede a las personas debe ser real y vinculado a la vida, siempre como expresión y manifestación de ella. Los imaginarios para Cornelius Castoriadis influyen directamente en las acciones e interrelación de los jóvenes con el mundo que los rodea y en la vida: "el conocimiento y la acción del hombre son, pues, indisociablemente psíquicos y social - históricos, dos polos que no pueden existir el uno sin el otro, y que son ireductibles el uno al otro" (Cisneros María E. 2011, p. 42)

En consecuencia, la influencia de los imaginarios constituye una fuerza incontenible cuya capacidad de transformación y generación de nuevas situaciones le dan el carácter de instituible. Este fue un aspecto relevante para la construcción de esta investigación puesto que no sólo se pretendía indagar y comprender los imaginarios sino que a partir de los mismos jóvenes la institucionalización de prácticas válidas paraellos con respecto a la corporalidad. 
IMAGINARIOS SOCIALES FRENTE A LA CORPORALIDAD

En la naturaleza instituyente de los imaginarios Cornelius Castoriadis (Citado por López Calderón, G. y León Ramírez A. 2013, p. ) sostiene que ésta parte de la experiencia de cada sujeto y del lenguaje. Mientras la experiencia modifica los imaginarios el lenguaje puede limitar la consolidación del mismo, puesto que depende en su mayoría de las instituciones o colectivos. Cornelius Cornelius Castoriadis expone que el pensamiento es esencialmente histórico y hace parte de la construcción de la subjetividad del individuo. Resulta interesante como la dicotomía entres sociedady sujeto realiza engranaje, un joven es el resultado de una sociedad un constructo claramente indentificable, mientras la sociedad se convierte a la vez en una auto- creación siendo un proceso intrínseco y subjetivo de cada quién.

Es obvio que la subjetividad matiza los imaginarios sociales desde los constructos individuales para ampliarlos a los colectivos. Resulta interesante para teorizar desde la subjetividad los imaginarios sociales el aporte del filósofo Carlos Moya (1996. Citado por López Calderón, G. y León Ramírez A. 2013), este autor plantea tres estados de la subjetividad denominados: intencional, sensitivo y práctico. (p.32)

Estos tres estados facilitaron la interpretación de los hallazgos obtenidos para comprender los imaginarios sociales de la corporalidad de los jóvenes. Conceptualmente el estado intencional subjetivo se refiere al:

“punto de vista que incluye de modo especial, la posesión de creencias y deseos, o de estados análogos a estos, caracterizados por la tensión y discrepancia potencial entre ellos y la realidad de las cosas; el segundo aspecto denominado "sensitivo" referido a la posesión, por parte del sujeto, de cierto nivel de sensibilidad, sensaciones y sentimientos, a los cambios en el entorno y en sí mismo; y un tercer aspecto de la subjetividad llamado "práctico" que se refiere a la capacidad del sujeto de desarrollar una actividad (p. 31) 
Finalmente, los imaginarios sociales representan un constructo colectivo e individual mediado por la subjetividad cuyas consolidación atañe al uso del lenguaje y a la influencia de la cultura, por lo tanto indagar el pensamiento de los jóvenes es relevante porque determina la realidad de los estudiantes y orienta claramente las acciones pedagógicas y educativas que procuren la conceptualización de la corporalidad en los adolescentes.

\section{La corporalidad es cuerpo y libertad}

La afirmación de Merleau- Ponty (Citado en López Saénz, M. 1996): “somos en el mundo con los otros" establece la complejidad del concepto de corporeidad corporalidad. La corporalidad se consolida desde una base filosófica debido a que solamente su definición se establece sobre la razón de la existencia humana. En este caso y ante la presencia del cuerpo, la carne propia y ajena fundamenta y complejiza alrededor de reconocer la transcendencia del ser humano y de los objetos.

En este sentido, Merleau.- Ponty reconoce la corporeidad como un estamento intersubjetivo e interpersonal, es decir, la alteridad y el otro estan presentes. Los jóvenes conocen de antemano la transcendencia ímplicita en la relación con sus pares y la corporeidad expresada en la presencia de estudiantes de su misma edad. (p.229)

En consecuencia, la corporalidad, el ser y el individuo conforman un conjunto de dimensiones transmitibles al mundo a través del cuerpo físico. La presencia del ser en el mundo implica una amalgama de reconocimientos subjetivos y objetivos. El ser humano amolda el cuerpo al mundo que lo rodea. Para ello posee capacidades físicas e 
IMAGINARIOS SOCIALES FRENTE A LA CORPORALIDAD

intelectuales que le favorecen en la búsqueda de identidad social, la cual le permite interactuar con los demás seres. Es claro, que los adolescentes parten de la percepción de su propio cuerpo e imaginarios para obtener identidad social y autoafirmación.

El cuerpo es un instrumento de la existencia humana. Su condición permite que el ser sujete el mundo que lo rodea, de tal manera que el establecimiento de una relación entre el cuerpo y el mundo para generar conductas individuales y sociales en un tiempo/espacio; en este caso, en el ambiente escolar se espera que a través de la comprensión de los imaginarios de la corporalidad establezcan relaciones humanas de calidad, disminuya el matoneo y cada adolescente afirme su identidad y logre identificar valores que garanticen una convivencia humana, sin olvidar la explosión de creatividad e imaginación que a través de la corporalidad genera en los estudiantes.

Hablar de corporalidad es determinar el objeto de la misma fundamentado en la permanencia del cuerpo propio. La permanencia del cuerpo propio es un medio de comunicación con el mundo. El sujeto observa las cosas exteriores con su cuerpo pero a su cuerpo no lo observa, ya que para que esto fuera posible sería necesario un segundo cuerpo. Ferrante, C. (s.f.) afirma que:

“en cuanto ve o toca el mundo, mi cuerpo no puede, pues, ser visto ni tocado; esto lo ilustra a través del ejemplo del entrelazamiento de las manos, en donde ambas manos poseen la doble función de ser tocantes y tocadas" (p.5).

El cuerpo es el fundamento de una serie de emociones, a causa de ello actúa como objeto y/o sujeto, es capaz de ver y sufrir. La práctica de la comunicación con el mundo involucra el cuerpo en la presencia externa del acto comunicativo. 
IMAGINARIOS SOCIALES FRENTE A LA CORPORALIDAD

Conceptualmente la corporalidad es el conjunto de acciones que el cuerpo es capaz de realizar de manera interna como externa, para ello la emocionalidad en los aspectos psicológicos, sociales y simbólico favorecen la dimensión del cuerpo en su vida corporal y su significado. Pedraza, Z. (s.f.) afirma que más allá de sus cualidades puramente orgánicas, el cuerpo y la corporeidad permiten al ser humano ser consciente de ella a través de la cenestesia y, luego, establecer vínculos emocionales mediante el cuerpo (p. 66)

A partir de este concepto, la sociología contemporánea plantea que la concepción social del cuerpo establece la apreciación social de su representación física. Es decir que el cuerpo es afectado por distintas concepciones sociales y a la vez está inmerso en disciplinas como la antropología, la bio-sicología, en las que se da por hecho que el cuerpo en su individualidad solo actúa si cuenta con la cenestesia. Esta es única y exclusiva del individuo vivo, además que le lleva a establecer una subjetividad incipiente con el fin de reafirmar en el sujeto su existencia.

Retomando a Merleau- Ponty (Citado en López Saénz, M. 1996) el cuerpo a través de la corporeidad establece relaciones de conocimiento del otro y del diálogo; un diálogo cuyo lenguaje y expresividad se fundamenta en la intersubjetividad transcendental. Merleau- Ponty manifiesta que solamente esa intersubjetividad aparece bajo el concepto filosófico de la carne o reversibilidad. La carne o reversibilidad, para Merleau-Ponty se caracteriza "siempre mediante metáforas e imágenes que expresan duolicidad: dentro y fuera, anverso y reverso, identidad y diferencia, sensación e intelección, yo y otro, etc.” (p.225) 
IMAGINARIOS SOCIALES FRENTE A LA CORPORALIDAD

Estos sustentos contribuyen en la afirmación del cuerpo como procurador de la corporalidad. Uno de los aspectos en la definición de la corporalidad se basa en la fenomenología del cuerpo, abarca la dimensión corpórea de la existencia humana y ofrece una nueva visión filosófica del cuerpo, en tanto que el cuerpo no es sólo una realidad observable como objeto, sino que es una dimensión del propio ser, pues como lo plantea Merleau-Ponty, desde la fenomenología de la existencia corpórea, el cuerpo es el medio de nuestro ser hacia el mundo. Es por eso precisamente que se puede afirmar de un modo radical que el ser en el mundo.

Heidegger afirma que (Gebauer y Wulf, 1998; Waldenfels, 2000, citados por Runge, 2004) el sujeto es ante todo un ser corporal en el mundo. Esto implica una pertenencia al mundo, a un hallarse implicado en el mundo a través del cuerpo y que el cuerpo abre a un sujeto al mundo.

Tal como lo expone Merleau Ponty no se debe observar el cuerpo como un objeto sino más bien hay que darle el valor y el sentido único que otorga la posibilidad de existir en el mundo tangible. Hay varios rasgos que identifican el ser corporal en el mundo, entre ellos: el cuerpo es nuestro anclaje en el mundo; el cuerpo porta en sí el punto cero o punto de referencia de todas las orientaciones, puesto que todas las cosas circundantes poseen su orientación relativa al cuerpo; el cuerpo es entendido como sujeto de capacidades; el cuerpo es modo de expresión; el cuerpo se convierte en sujeto de la percepción, aquí el cuerpo puede ver y ser-visto, tocar y sertocado; el cuerpo al estar abocado al mundo exige que sea entendido como sujeto de espacio y de tiempo; y el cuerpo es intersubjetividad- intercorporalidad. 
IMAGINARIOS SOCIALES FRENTE A LA CORPORALIDAD

Según la psicología clásica, el cuerpo era concebido como un objeto que podía ser percibido constantemente, convirtiéndolo así en una mera "representación". Para Merleau-Ponty, el cuerpo no puede ser concebido como un objeto, ya que no puede estar nunca plenamente constituido dado que gracias a él existen los objetos. La permanencia del cuerpo es una permanencia absoluta que posibilita la constancia relativa de los objetos exteriores.

Sin embargo, el cuerpo dimensionado en la corporalidad según Merleau-Ponty (Citado por López Saénz, M. 1996). fundamenta en la libertad del sujeto gracias a la alteridad: la libertad ajena confirma la mia, aunque así la limite, y la confirma precisamnete como la libertad limitada. Merleau- Ponty nos propone la dialéctica conciencia - mundo, ego- alter, solipsismo- comunicación. (p. 223)

Merleau - Ponty establece la intersubjetividad como un recurso propio para explorar el fenómeno del cuerpo, la corporalidad se enmarca en la conciencia y cuerpo. Vale entonces, que los jóvenes fundamenten el conocimiento del cuerpo a partir de la constitución de un esquema corporal. El esquema corporal implica la percepción propia con relación al medio que habita el sujeto. Estas aclaraciones permiten tanto al sujeto como al otro a reconocer y a diferenciar características propias y ajenas, para Merleau - Ponty, hay correlación entre la conciencia del cuerpo propio y la percepción del otro. (López Saénz, M. 1996. p. 61)

Definiendo la corporalidad es necesario considerar los procesos de percepción de los sujetos. La percepción de las conductas de un cuerpo se manifiestan de la vida del otro. Corporalidad y alteridad van de la mano, en este sentido Merleau- Ponty (López Saénz, M. 1996) argumenta lo anterior para comprender la intersubjetividad según tres aspectos: el fenómeno del cuerpo del otro se presenta como una especie de duplicado de mi vida corporal, 
IMAGINARIOS SOCIALES FRENTE A LA CORPORALIDAD

los otros se le dan directarnente al yo y la apertura a una presencia común que hace posible en entelazamiento de la experiencia del cuerpo propio y su repercusión en la percepción del otro.

En conclusión, la construcción de la croporalidad se establece bajo el reconocimiento del otro y transportando a la subjetividad transcendental la existencia del yo y del otro. Desde la postura de la fenomenología existencial de Merlenau- Ponty la existencia de cada quién implica estar en el mundo con los otros, ya sean sujetos u objetos. La corporeidad reconoce la co-existencia y el yo- otro.

Le Breton, David (2002) define la corporeidad humana como un fenómeno social y cultural, reconoce su materia simbólica y como objeto de representaciones e imaginarios. Los actos humanos o acciones desde las sencillas a las comlejas, íntimas o individuales a públicas y colectivas implican la intervención de la corporeidad, puesto que no solomente la vida humana y el cuerpo experimentan desde la actividad perceptiva también debe realizar significaciones representativas del mundo que los rodea. (p.15)

Para Le Breton las incidencias sociales del cuerpo se fundamentan en que el hombre es concebido en un medio social y cultural, sin embargo, el hombre también es produto de su cuerpo. Le Breton considera que la corporeidad no es un efecto de la condición social del hombre sino que al contrario la condición social produce directamente su cuerpo. La corporeidad se construye socialmente. Por lo anterior, los jóvenes y/o adolescentes alcanzan su mayor participación en medios sociales y en compañía de sus pares o amigos.

Así mismo Le Breton afirma que el cuerpo es un elemento del imaginario social, las sociedades establecen generalmente la relación de la existencia con el cuerpo y de acuerdo a la 
IMAGINARIOS SOCIALES FRENTE A LA CORPORALIDAD

cultura existen numerosas concepciones y variablidad. Existe dos posturas clásicas en estas concepciones.

En las sociedaddes tradicionales con un componente comunitario, la sociedad subordina por completo el colectivo a lo individual, los grupos establecidos en este tipo de sociedades diluyen la individualidad y por lo tanto el cuerpo se identifica como un objeto y no se distingue de las personas. El cuerpo liga la energía colectiva, se cuenta que con la presencia del cuerpo cada persona sea incluida en el grupo social.

En las sociedades individualistas, el cuerpo se identifica como el interruptor que marca los límites de la persona, en palabras de Le Breton es “donde comienza y termina la presencia de un individuo" (Le Breton, David 2002. p. 32)

Finalmente, el contexto actual y la significación del cuerpo se traduce en la adoración del cuerpo, esta afirmación simboliza una de las máximas expresiones de la tendencia de nuestros días. Vivimos en la era de la imagen., es decir de la apariencia, lo externo, el porte, la forma como cada quien se muestra ante los demás. Los clásicos ya lo decían: debe haber una buena relación entre lo externo e interno del ser humano. Sin embargo existen varios conceptos inmersos. Hay muchas vicisitudes que se hospedan en esta devoción al cuerpo: el mito de la eterna juventud, el conjunto de las apariencias, el elogio de la mujer muy delgada; dentro de un contexto en el que los medios de comunicación resaltan la apariencia física de una manera porfiada y la industria cosmética ofrece una amplia gama de productos para mantener esa fachada. 
IMAGINARIOS SOCIALES FRENTE A LA CORPORALIDAD

Cada época presenta sus preferencias. La moda se propaga fácilmente y se impone con sus conductas sociales. Esta prelación hacia la belleza corporal y facial ha llevado a ubicar en

primer plano la divinización del cuerpo y la exaltación de un tipo específico de belleza, que hoy se establece ampliamente en la sociedad. Esto genera en el ser humano una obsesión por su apariencia física, llegando en ocasiones a producir tristeza, malestar, angustia y hasta depresión.

Actualmente el cuerpo actúa como una herramienta de enlace social para la aceptación del individuo. Se concibe la perfección estética como un modelo a seguir y con el cual se obtiene un posicionamiento dentro de una colectividad enmarcada por parámetros de belleza corporal, que afectan aspectos sicológicos de las personas.

\section{La adolescencia fundamento de la corporalidad}

Las referencias conceptuales de la adolescencia enmarcan un período de crecimiento y desarrollo corporal transicional que se encuentra entre el final de la infancia y el comienzo de la juventud. Alrededor de los 10 años los niños y niñas comienzan su desarrollo corporal, intelectual, emocional determinante en la búsqueda de identidad y la definición de "ser alguien en este mundo". En el año 2002 se calculó la mayor tasa de población adolescente en el mundo superando la infantil, alrededor de 1.200 millones de jóvenes con edades entre los 10 y 19 años. Nelson Mandela (Citado en Fondo de las Naciones Unidas para la Infancia UNICEF, 2002) expresó con determinación la importancia de esta etapa en el ser humano dirigiéndose a los jóvenes con estas palabras:

\footnotetext{
"Mis queridos jóvenes: Veo la luz de vuestros ojos, la energía que emana de vuestros cuerpos, y la esperanza que impregna vuestras almas. Sé que sois vosotros, y no yo, quienes levantaréis el futuro. Que vosotros, y no
} 
IMAGINARIOS SOCIALES FRENTE A LA CORPORALIDAD

yo, rectificaréis nuestros errores, y haréis suma y sigue con las cosas buenas de este mundo" (p.5)

Para la UNICEF, el adolescente se encuentra en una de las fases de la vida más compleja, es allí donde el niño joven asume mayores responsabilidades y comprende el sentido de la libertad con el deseo inmenso de vivirla. Logran independencia y buscan su propia identidad, es claro que la adolescencia y las vivencias solamente pueden experimentar a la luz de la práctica de los valores impartidos en el período de la infancia. Segun la UNICEF la adolescencia es un período que facilita al individuo desarrollar habilidades para luego conformarse en la adultez como una persona responsable, sin embargo, este período de transición no resulta para el joven, en ocasiones su estado será de una alegría incontenible para luego pasar a la depresión o tristeza. En esta etapa, los modelamientos de los adultos son determinantes en la adopción de las conductas y actitudes del futuro adulto. Por esra razón, la intervención educativa es fundamental para los jóvenes.

El Fondo de las Naciones Unidas para la Infancia UNICEF, (2002) expresa que los adolescentes pueden desarrollar habilidades en cada uno de los campos del desempeño humano. Sin embargo, solamente con el apoyo y aliento de los adultos que rodean estos jóvenes lograrán la participación y contribución tanto en su familias como en las comunidades. En este sentido, la escogencia de la población objeto de este estudio en el rango de la adolescencia presupone para la Educacion Física contribuciones en una esfera humana con miras al bienestar humano a lo largo de la vida. La UNICEF reconoce a los adolescentes con características particulares como la curiosidad, energía, creatividad, espíritu y entusiasmo (p.3) 
IMAGINARIOS SOCIALES FRENTE A LA CORPORALIDAD

La adolescencia es un período de transición que ocasiona cambios físicos, crecimiento de extremidades superiores e inferiores y aumento de la masa muscular. La maduración sexual aparece junto con el aumento de la capacidad para razonar de forma abstracta, logran la confrontación de los hechos reales en contraposición con la fantasía e imaginación de la infancia. Es el tiempo de determinar los actos buenos y diferenciar con claridad de los actos malos. Por último, los adolescentes se caracterizan por meditar y pensar sobre su futuro y razón de existencia. (Fondo de las Naciones Unidas para la Infancia UNICEF, 2002. p. 4)

Moses Laufer (1928-2006), define la adolescencia "como una fase evolutiva (de desarrollo) y de la juventud (Young adulthood), como un tiempo (una época) en el que el desarrollo estructural se fija y cuando el carácter está menos dispuesto a cambiar" (1976, p.297); así pues, la adolescencia puede definirse como la asimilación e integración de los cambios fisiológicos de su cuerpo, los cuales una vez integrados le permiten acceder al mundo adulto.

A diferencia de colectividades donde el paso de la niñez a la edad adulta era marcado por una ceremonia iniciática que le daba acceso al infante al mundo de los mayores, en la actualidad la adolescencia fue creada de manera artificial para definir la etapa que media entre el momento en el que el sujeto deja de ser niño y el inincio a la vida de los adultos.

Sin embargo, es necesario mencionar que los adolescentes hoy en dia se encuentran amparados en derechos que establecen el reconocimiento e identidad como jóvenes, al respecto Kofi Annan, Secretario General de las Naciones Unidas afirmó: “Una sociedad que se aísla de sus jóvenes, corta sus amarras: está condenada a desangrarse" (Fondo de las Naciones Unidas para la Infancia UNICEF, 2002. p. 8). Es claro que la mayor esperanza de cambios drásticos de las realidades mundiales pueden resolverse en la medida que se escuche el pensamiento y sentir 
IMAGINARIOS SOCIALES FRENTE A LA CORPORALIDAD

de los jóvenes y luego hacerlos partícipes de acciones encaminadas al bienestar individual y colectivo.

En concordancia, los movimientos histórico-filosóficos han hecho hincapié en diversos aspectos del adolescente para derivar una definición acerca del mismo. Entre estos aspectos han sido considerados la emoción, el sentimiento, la pasión y la exaltación de los valores como manifestaciones de esta etapa. En otras épocas la capacidad sexual, por ejemplo, fue reprimida durante la etapa de latencia, sirviendo para caracterizar también la fase adolescente (Rocha, 2011, p.457).

Más tarde los trabajos de Jacques Lacan refieren el encuentro con la corporalidad en el estadio del espejo (Lacan, 2009, p.99), quien habló de un real, imaginario y simbólico, así como de un cuerpo de significaciones. Por otro lado, Rocha (2011) afirma que la conceptualización de la adolescencia varía de acuerdo a las concepciones del conocimiento, en sus propias palabras:

"Se han dado diversos conceptos acerca de la adolescencia. Una de las concepciones que ha cobrado gran importancia y que ha permitido desplegar de ella a diversas propuestas teóricas de importancia, es la que liga este estado con la corporalidad. Todo ser humano tiene una representación de su propio cuerpo, la cual llega a formarse a través de años y le acompaña toda su vida. Esta representación puede ser o no aceptada por el sujeto que la porta” (p.456)

Ello conlleva diversos estados de madurez mental del sujeto y su propensión a manifestar comportamientos poco saludables; anteriormente, y durante muchos años, existió una concepción platónica dual cuerpo-alma que apartaba cada uno de estos aspectos y mantenía una división en la concepción de la naturaleza humana. La imagen corporal se configura a partir de un proceso 
IMAGINARIOS SOCIALES FRENTE A LA CORPORALIDAD

ritual en el que se van significando evidencias sobre el cuerpo del sujeto que contienen un

sentido cultural y que se anclan en el cuerpo a partir de la experiencia, por ello involucra la

sensación, la percepción, su afectividad y su proceso cognitivo; es decir su corporalidad. En esta

concepción los procesos culturales son siempre inclusivos de los procesos físico-orgánico-

biológicos y psicológicos.

En este orden de ideas, reconocer los imaginarios sociales para comprender la realidad de los adolescentes constituye un recurso valioso, así lo afirma Gergen (2007. Citado por Quiceno Gil, L. C., Zapata Pérez, L. M. y Pulido Varón, H. S., 2016, p.112) quién conceptualiza los imaginarios como una transpolación de lo interno en lo externo: "El conocimiento se obtiene cuando los estados internos del individuo refejan o representan de manera precisa (o sirven como espejo de) los estados existentes del mundo exterior" (p. 214)

En este sentido, los adolescentes no solo infieren conocimientos a partir de su individualidad, existe una fuerte influencia del mundo que los rodea en las conceptualizaciones, sentimientos, opiniones y valores que emanan de sus actos o conductas diarias frente a diferentes temas.

En la investigación Imaginarios sociales de 27 jóvenes de grado 11 sobre Medellín la más Educada, en una institución del nororiente de la ciudad: Institución Educativa Ramón Múnera Lopera, los adolescentes no solo construyen sino que aprenden y validan sus experiencias en relación con el otro y la existencia de las dinámicas cotidianas y reales que los rodean a partir de los imaginarios que emergen de esa interrelación. 
IMAGINARIOS SOCIALES FRENTE A LA CORPORALIDAD

No en vano, Naval (2005) afirma que "la etapa juvenil es la dicotomía que se da entre ideales y vida real cotidiana" (...) "por un lado, la fuerza de la personalidad que se autoafirma y la vitalidad que todo lo pregunta" (Citado por Quiceno Gil, L. C., Zapata Pérez, L. M. y Pulido Varón, H. S., 2016 p.113). Sin duda, los imaginarios construyen en el joven una dimensión individual también desde lo político, social y cultural. Por esta razón, una investigación que dé cuenta de los pensamientos en los adolescentes genera cambios sustanciales en cuanto a la educación y formación de las personas.

Un imaginario social involucra a la vez la consolidación de un grupo y un escenario. Quiceno Gil, L. C., Zapata Pérez, L. M. y Pulido Varón, H. S. (2016) validan la idea de la juventud como un grupo etario con fuerza y convicción para cambiar, transformar y participar en diferentes escenarios educativos, recreativos, sociales y culturales. Los jóvenes pueden generar no solo espacios sino escenarios valiosos de formación y crecimiento donde den cuenta de prácticas sociales, deseos o aspiraciones que afiancen los procesos de inclusión, o "creando espacios alternativos donde se den momentos de expresión propia, de búsquedas y de resignificaciones como grupo" (Jurado, Romero, Zulúaga, \& Jiménez, 2012. Citado por Quiceno Gil, L. C., Zapata Pérez, L. M. y Pulido Varón, H. S. 2016, p. 113)

En concordancia, los escenarios donde participan los adolescentes desencadenan imaginarios sociales que dan cuenta de las dinámicas culturales, creencias y pensamientos del medio social. Es necesario, entonces escuchar y comprender las posturas que tienen los adolescentes, así como las realidades que construyen, las experiencias y la carga histórica que le dan significados particulares en el desenvolvimiento, respuestas sociales e individuales frente a los diferentes temas incluyendo la corporalidad. 
IMAGINARIOS SOCIALES FRENTE A LA CORPORALIDAD

Así mismo, los imaginarios legitiminan las realidades de cada grupo humano. Cegarra (2012) afirma que el "imaginario social es un esquema referencial para interpretar la realidad socialmente legitimada e históricamente determinada" (...), “ el imaginario es interpretativo" (Citado por Quiceno Gil, L. C., Zapata Pérez, L. M. y Pulido Varón, H. S. 2016, p. 113).

Pensar los imaginarios como interpretativos de las realidades supone el reconocimiento de cada grupo social, en este caso, los adolescentes y las ideas, opiniones y sentires que las personas forman a partir de las experiencias y los conocimientos que poseen; esto incide directamente en cómo ven y se relacionan con el mundo.

Así mismo, Aguayo Rousell, Hilda B. (s.f) manifiesta que la conciencia individual y colectiva de un objeto son las representaciones sociales. Éstas a la vez, dependen de cada quién y de su situación social, cultural, profesional, emocional, económica y del conglomerado de códigos culturales que conforman la individualidad y colectivo de cada quién. Los jóvenes o adolescentes no son ajenos a estas representaciones, en realidad, el intercambio o relaciones cotidianas se dan en la medida que el contacto con grupos sociales sea posible. Moscovici (1961. Citado por Aguayo Rousell, Hilda B. s.f) afirma: “(...) los hombres hacen inteligible la realidad física y social se integran en un grupo o en una relación cotidiana de intercambios”(p. 3)

En relación con lo anterior, el trabajo investigativo titulado Medios de Comunicación y Corporeidad: Representaciones Sociales de los Educadores Físicos, relaciona de forma directa los núcleos temáticos de esta investigación. Es claro para Aguayo Rousell que la imagen corporal real puede confundirse con la imagen virtual consolidada en la gran mayoría; se imagina a través del bombardeo de los ideales que proyectan los medios de comunicación, hoy en día, los jóvenes tienen modelos desde los ámbitos deportivos, la publicidad, el modelaje o la cultura fitness estimulados por el torrencial de los medios de comunciación e información, asi 
IMAGINARIOS SOCIALES FRENTE A LA CORPORALIDAD

como las redes sociales donde se exalta con mayor preferencia la belleza exterior, los cuerpos moldeados y sanos exteriormente en contra del bienestar emocional. En estas transformaciones, los jóvenes se ven expuestos a contradicciones en cuanto al cuerpo que ven en la televisión o en las pantallas y lo que realmente se ve en la cotidianidad, en la calle o en el mismo espectador que observa en el interior del hogar.

Ahora bien, situar los imaginarios sociales de los estudiantes con respecto a la corporalidad requiere la identificación del modelo de cuerpo que difunden los medios de comunicación a una imagen virtual o imaginaria, es decir, no real. La corporeidad "edifica la imagen corporal desde la realidad del cuerpo y promueve la aceptación del cuerpo experimental y vivido como parte inherente del proceso de crecimiento del individuo" (Aguayo Rousell, Hilda B. s.f., p. 3)

En este artículo, Aguayo Rousell, Hilda B. (s.f.) resalta la importancia y el rol del Educador Físico en la sociedad mexicana, enfatiza sobre la necesidad de proyectar en los estudiantes una imagen de corporeidad acorde a los estándares de salud física y emocional para transcender en cada uno de los espacios de los jóvenes con miras a procurar el bienestar integral. En concordancia, el artículo La Educación Física como espacio de transformación social y educativa: perspectivas desde los imaginarios sociales y la ciencia de la motricidad humana, desarrollado por Alejandro Almonacid Fierro en el año 2012 aborda el fenómeno de la educación física como posibilidad de transformación humana, articulando los enfoques del imaginario social y la emergente perspectiva de la motricidad educativa. El despliegue didáctico de este sector de aprendizaje se ha caracterizado por el predominio de una lógica instrumental, tecnológica y positivista, que invisibiliza las complejas dimensiones de la persona humana, generando un reduccionismo ontológico que privilegia el desarrollo de un cuerpo funcional que 
IMAGINARIOS SOCIALES FRENTE A LA CORPORALIDAD

permita alcanzar altos estándares de producción y, por consiguiente, de desarrollo económico, lo que conduce al debilitamiento de las nociones de sentido, significado y trascendencia tan propias del vivir humano en la relación yo, otro, sociedad. En este contexto, la motricidad educativa tiene la noble tarea de reencontrar al ser humano con su subjetividad, ponerla en relación con el otro, e iniciar los procesos de mudanza necesarios para alcanzar el preciado desarrollo humano y una sociedad mejor.

Asi mismo, pensar la labor del Educador Físico como una tarea aislada es considerar que los imaginarios sociales solo se desencadenan al interior de cada quién, es por esta razón, que la Educación Física encuentra razón de ser e impacto en el ámbito educativo o escolar; al respecto Aguayo Rousell, Hilda B. (s.f.) sostiene que la labor principal de la escuela es procurar los procesos de construcción permanente de la corporeidad de los estudiantes, el cuerpo es el centro del aprendizaje, razón fundamental para generar actividades físicas placenteras, lúdicas, dirigidas o libres, sistemáticas y sobretodo saludables. Aguayo (Citado por Gómez, 2002: 103 en Aguayo Rousell, Hilda B. s.f.) afirma que:

“las prácticas de los educadores físicos han de ser conscientes y responsables de la transcendencia de su papel en el ámbito educativo, promoviendo uan axiología de los usos del cuerpo y del movimiento corporal y enfatizando la significatividad personal que conlleva la conciencia corporal y la realización de actividades físicas que superen estereotipos discriminatorios por motivos de género, étnicos, sociales u otros en la asignación de patrones respecto a los usos del cuerpo" (p. 4)

Por otro lado, en el artículo Orientación Educación Física. Educación Física y Corporeidad (s.f) la afirmación del concepto de la corporeidad como una construcción humana 
IMAGINARIOS SOCIALES FRENTE A LA CORPORALIDAD

que da sentido al cuerpo y su funcionamiento biológico, establece en esencia que la constitución del ser humano involucra imaginarios alrededor de las circunstancias de la existencia humana. Transportan lo biológico al contexto diario, vivible y a partir de sus propios

valores, filosofía y el libre albedrío permite determinar cómo quiere vivirlo, construirlo, imaginarlo y determinar su uso.

De igual manera, expone la transformación de los imaginarios sociales acorde a la cada época histórica, es obvio que a lo largo del tiempo la dimensión corporal ha sido valorada o subvalorada. En la actualidad, los enfoques sobre el tema decantan en diferentes consideraciones asemejadas al valor de lo estético y cuerpos perfectos que tanto estudiantes como profesores necesitan identificar, valorar, asumir y darle significado acorde a su escala de valores.

Las investigaciones cuyos resultados aporten en el tema de la corporalidad suponen en el campo de la Educación Física el reconocimiento de la dimensión corporal y sus construcciones a lo largo del crecimiento y vivencias humanas. En este sentido, el abordaje de la educación del cuerpo no sólo se puede limitar al aprendizaje de ejercicios o técnicas motrices. Es claro, que en este proceso de constitución corporal, el docente de educación física cumple con un rol de facilitador que “(...) propicie en los estudiantes la asunción de posiciones críticas respecto de imágenes externas y modelizadas del cuerpo, en función de sus intereses personales" (Orientación Educación Física. Educación Física y Corporeidad. s.f. p. 9)

En concordancia, varias investigaciones han generado intereses no solo por indagar los imaginarios sociales, también centrar su campo de acción en la intervención directa con grupos de adolescentes teniendo en cuenta la particularidad de esta etapa de desarrollo humano. Sin 
IMAGINARIOS SOCIALES FRENTE A LA CORPORALIDAD

objetar las implicaciones psicológicas, emocionales, biológicas que transitan de la infancia a la juventud para consolidar al adulto como tal. 


\section{Metodología}

La aproximación a los imaginarios sociales frente a la corporalidad de los estudiantes de grado décimo del colegio Leonardo Posada Pedraza I.E.D., en la Localidad de Bosa requirió para esta investigación un trabajo de tipo participativo, de inmersión e interacción permanente con los jóvenes.

El trabajo de campo permitió caracterizar los usos corporales que predominan en los adolescentes con respecto a los imaginarios de la corporalidad e identificar los factores que influyen en los imaginarios de los adolescentes en cuanto a corporalidad y bienestar. En consecuencia, estos hallazgos permitieron proponer lineamientos para la creación de procesos de acompañamiento e intervención con el fin de construir resignificaciones frente a la corporalidad en jóvenes escolares en un futuro inmediato.

Este trabajo investigativo se realizó en varias etapas partiendo de la recogida de información, entrevistas, selección de la muestra, aplicación de entrevistas semiestructuradas para llegar, por último al análisis e interpretación de datos.

\section{Tipo de Investigación}

El carácter del ambiente escolar del colegio Leonardo Posada Pedraza I.E.D en la Localidad de Bosa facilitó la adopción de la etnometodología de corte descriptivo. La 
IMAGINARIOS SOCIALES FRENTE A LA CORPORALIDAD

etnometodología es un tipo de investigación cualitativa. Este enfoque permitió explorar los imaginarios de los estudiantes bajo un ambiente natural y los significados para comprender a los jóvenes frente al tema de la corporalidad, pues de allí mismo fueron extraídos los datos. Para llevar a cabo esta investigación no se plantearon hipótesis de comprobación y los resultados no se fundamentaron en la estadística. La recolección de datos permitió y facilitó el análisis de múltiples realidades subjetivas al reconocer la cotidianidad de los estudiantes, hábitos y estilos de vida. Este proceso no fue lineal.

El enfoque cualitativo de esta investigación permitió contextualizar los imaginarios sociales y ampliar las ideas respecto a los conocimientos de la corporalidad, así como los conceptos de salud, bienestar, usos y expresiones corporales. Lo anterior, facilitó la comprensión mediante la descripción de los imaginarios sociales frente a la corporalidad de los estudiantes de grado décimo del Colegio Leonardo Posada Pedraza I.E.D.

La obtención de los hallazgos se logró mediante el método de grupo focal e indagación a profundidad semiestructurada. Se empleó este método debido a que el ambiente de grupo generaba una atmósfera de seguridad en la cual los participantes no se sentían presionados para responder a cada una de las preguntas formuladas. Las características propias de la edad de la población sujeto de estudio facilitaron la aplicación cualitativa en cuanto a la capacidad de apertura al diálogo en las entrevistas y charlas. Este método abrió espacio a experiencias importantes que a través del proceso investigativo se vivenciaron de manera espontánea y natural.

Al tratarse de una población estudiantil mixta de adolescentes, este enfoque aportó también un punto de vista fresco y natural de los fenómenos, permitiendo así contextualizar temáticas propias del ambiente y el entorno. 
IMAGINARIOS SOCIALES FRENTE A LA CORPORALIDAD

A través de este método se pudo obtener mayor cantidad y variedad de respuestas que enriquecieron la información con respecto a los temas planteados, así como también se conocieron conductas y actitudes sociales importantes.

\section{Diseño metodológico}

El planteamiento del diseño metodológico partió de las fases, determinación de la población y selección de la muestra. También del establecimiento de las categorías de análisis.

\section{$\underline{\text { Fases }}$}

Esta investigación se determinó a partir de tres fases, la primera incluyó la recogida de información a un grupo de 30 estudiantes incialmente del grado décimo donde se aplicaron dos instrumentos: el cuestionario que permitió realizar una lectura de las necesidades de los estudiantes. Se realizó bajo la modalidad de preguntas cerradas. Ver Anexo F. El segundo instrumento fue la encuesta Fantástico. Ver Anexo G para deterrminar hábitos y estilos de vida.

La segunda fase incluyó la selección de la muestra final para el grupo focal y la aplicación de las entrevistas semiestructuradas para determinar los imaginarios sociales, los conceptos y usos de la corporalidad. En la tercera y última fase se realizó el análisis e interpretación de datos. En el siguiente diagrama se muestran los tiempos en años de esta investigación, alrededor de tres años y medio.

Figura 1. Diagrama Tiempos de ejecución de cada fase 


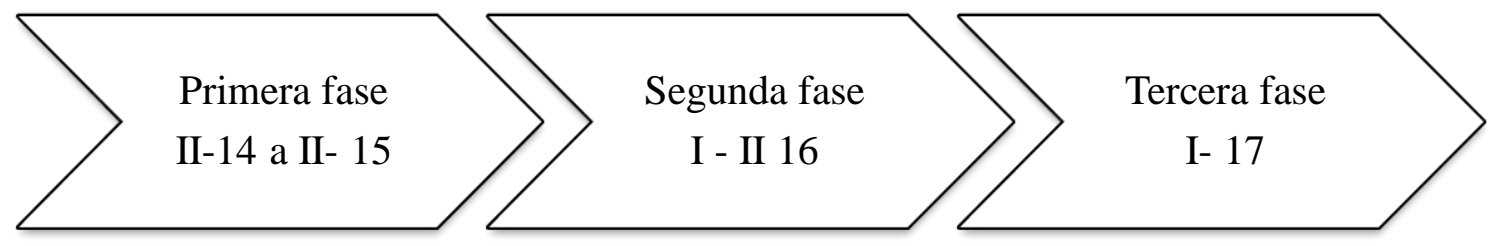

\section{$\underline{\text { Población }}$}

Inicialmente participaron 30 estudiantes pertenecientes al grado décimo del I.E.D

Leonardo Posada Pedraza jornada tarde. Se escogió este grupo porque estaba conformado por estudiantes con una edad y actitud apta para comunicarse y argumentar sus respuestas durante las entrevistas; además de ser un grupo en su mayoría extrovertido y dispuesto a llamar la atención de los demás al presentar cierta exageración en cuanto al uso de adornos corporales, tatuajes, pearcings, y extensiones entre otros. El grupo focal estuvo conformado por cinco estudiantes.

La investigación tuvo lugar en el Colegio Distrital Leonardo Posada Pedraza. Se obtuvo información tanto estudiantes que gustan de la práctica del ejercicio y la actividad física, como de estudiantes que no lo hacían con regularidad.

El Colegio Leonardo Posada Pedraza IED nace de la necesidad de garantizar el derecho a la educación de los niños niñas y jóvenes de la Localidad Séptima Bosa, específicamente en la UPZ 87 (Tintal Sur), cuyo crecimiento de población debido a la realización del proyecto habitacional de Metrovivienda de la Alcaldía Mayor de Bogotá hizo prioritaria la creación de 
IMAGINARIOS SOCIALES FRENTE A LA CORPORALIDAD

instituciones educativas para atender tan alta demanda. Hacia finales del año 2002, el Cadel proyecta la organización de una institución bajo la administración del Colegio San Bernardino, con el propósito de responder a esta necesidad. Se inicia con doce aulas distribuidas en el área social de los respectivos conjuntos comunales, con dos grupos de preescolar y diez grupos de primaria por jornada. En el año 2004 se ubican aulas prefabricadas en el lote destinado a la construcción del colegio, donde se da inicio a la educación básica secundaria y a la vez la construcción de la planta física actual. En agosto de 2005 el Alcalde Mayor de Bogotá D.C. Luis Eduardo Garzón le da vida oficial a nuestro Colegio, el primero de los mega colegios construidos y bautizado con el nombre de Leonardo Posada Pedraza.

En la actualidad la planta física cuenta con 36 aulas de clase, 10 aulas especializadas, auditorio, coliseo, biblioteca, área administrativa, zonas verdes y deportivas. La institución garantiza el derecho a la educación a una población superior a 3500 estudiantes, desde preescolar hasta grado once, con 108 docentes en total organizados en diferentes áreas y niveles, siete directivos docentes, dos orientadores y seis funcionarios administrativos. A partir del 30 de diciembre de 2011, mediante Resolución de Secretaría de Educación, el colegio es incluido en el grupo de colegios articulados con la educación superior, lo cual conlleva a ofrecer a nuestros egresados posibilidades de continuar su educación superior en el Servicio Nacional de Aprendizaje SENA.

\section{Categorías de Análisis}


IMAGINARIOS SOCIALES FRENTE A LA CORPORALIDAD

Se establecieron tres categorías analíticas denominadas: Imagen Corporal, Movimiento y Cuerpo, Concepto Corporal para llegar a los imaginarios sociales de la Corporalidad.

\section{Selección de procedimientos}

Inicialmente se emplearon cuestionarios y encuestas ya que se podían aplicar a un curso completo y a la hora de tabular la información evitó invertir demasiado tiempo en ello debido a que las opciones de respuesta eran predeterminadas. Luego se acudió especialmente a una encuesta en donde se obtuvieron datos principalmente relacionados con hábitos y estilo de vida. El nombre de la encuesta aplicada es Fantástico. Ver anexo G, fue un instrumento útil a la hora de observar las distintas formas que tenían los participantes al emplear su tiempo libre.

Posteriormente se aplicó la encuesta llamada Cuestionario de Lectura de Necesidades. Ver Anexo F, cuyos resultados obtenidos fueron sistematizados en gráficas, para llegar a las conclusiones correspondientes. Se dio paso a las entrevistas, ya que ellas dan al adolescente la posibilidad de sensibilizarse y expresarse con naturalidad frente a determinado tema.

A través de las entrevistas se logró captar distintas emociones, gestos, tono de voz, y el interés del estudiante por el tema mientras se expresaba o comunica algo.

\section{Condiciones de recolección de los datos}


IMAGINARIOS SOCIALES FRENTE A LA CORPORALIDAD

Para alcanzar los objetivos propuestos para esta investigación se establecieron tiempos de trabajo que involucró la participación de los adolescentes y del investigador, cuyo rol como educador fisico de la institución educativa, facilitó la inmersión en el campo de investigación.

Para el desarrollo de esta investigación se recogió información de estudiantes pertenecientes a uno de los grados décimo, mediante la aplicación del cuestionario de lecturas de necesidades y luego encuestas sobre hábitos y estilos de vida. Luego de analizar algunas pruebas piloto realizadas con los estudiantes, se hizo necesario acudir a la entrevista y reducir el número de la población para llevar a cabo una investigación más completa y detallada sobre un grupo específico.

Con las entrevistas semiestructuradas, se indagó acerca de los imaginarios sociales con respecto a la corporalidad, conceptos y usos sociales de los participantes. Así mismo fue necesario realizar un refuerzo o aclaración de conceptos relacionados con la corporalidad, debido a que se notó inseguridad en varios de ellos y se evidenció desconocimiento y confusión en ciertos temas.

\section{Técnicas e Instrumentos de recolección de información}

La observación participante y la entrevista constituyeron las técnicas para la recolección de datos, los instrumentos que se emplearon fueron el cuestionario y los asentimientos informados.

Figura 2. Diagrama de relación entre técnicas e instrumentos. 


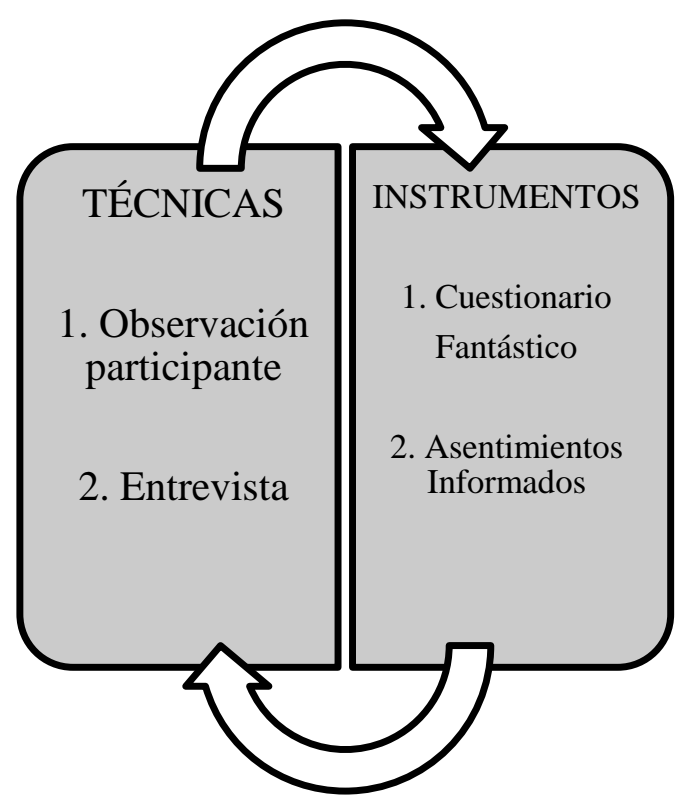

Así mismo, como instrumento se empleó el formato denominado Asentimiento Informado para estudiantes, Anexo A. Su diseño incluyó dos partes: Un documento escrito que proporciona información sobre el estudio de manera verbal al niño/estudiante y un formulario de Asentimiento que es un documento donde se firma si se está de acuerdo en participar. Anexo B.

Otro instrumento que se empleó fue el Anexo C denominado Consentimiento informado para padres de familia proyecto de investigación. Este Documento de Consentimiento Informado contuvo dos partes: Información: proporciona información sobre el estudio para cada padre de familia y un formulario de consentimiento para obtener la firma si el padre de familia está de acuerdo en que su hijo pueda participar. A cada padre de familia se le dió una copia del documento completo de Consentimiento Informado. 


\section{Análisis e Interpretación de Datos}

Para el análisis e interpretación de datos se empleó el análisis de contenido de tipo categorial, mediante procesos de codificación y vaciado en matrices. Los datos obtenidos fueron analizados e interpretados de acuerdo a las dos fases de trabajo de campo en el IED Leonardo Posada. Para el primer análisis se elaboraron gráficas de frecuencias absolutas tanto del primer cuestionario del Anexo F y G. Para la segunda fase el empleo de matrices permitió el análisis e interpretación de datos desde un enfoque descriptivo e interpretativo.

\section{Análisis e Interpretación de datos Primera Fase}

Los hallazgos se obtuvieron durante el segundo semestre del año 2014 y corresponden a los Anexos F y G. En el gráfico Nro. 1. Lectura de Necesidades, el consolidado de las respuestas a la encuesta relacionada con los aspectos generales, salud y actividad física fue realizada a 30 estudiantes, se obtuvieron 690 registros.

\section{Grafico Nro. 1}

\section{Lectura de Necesidades}




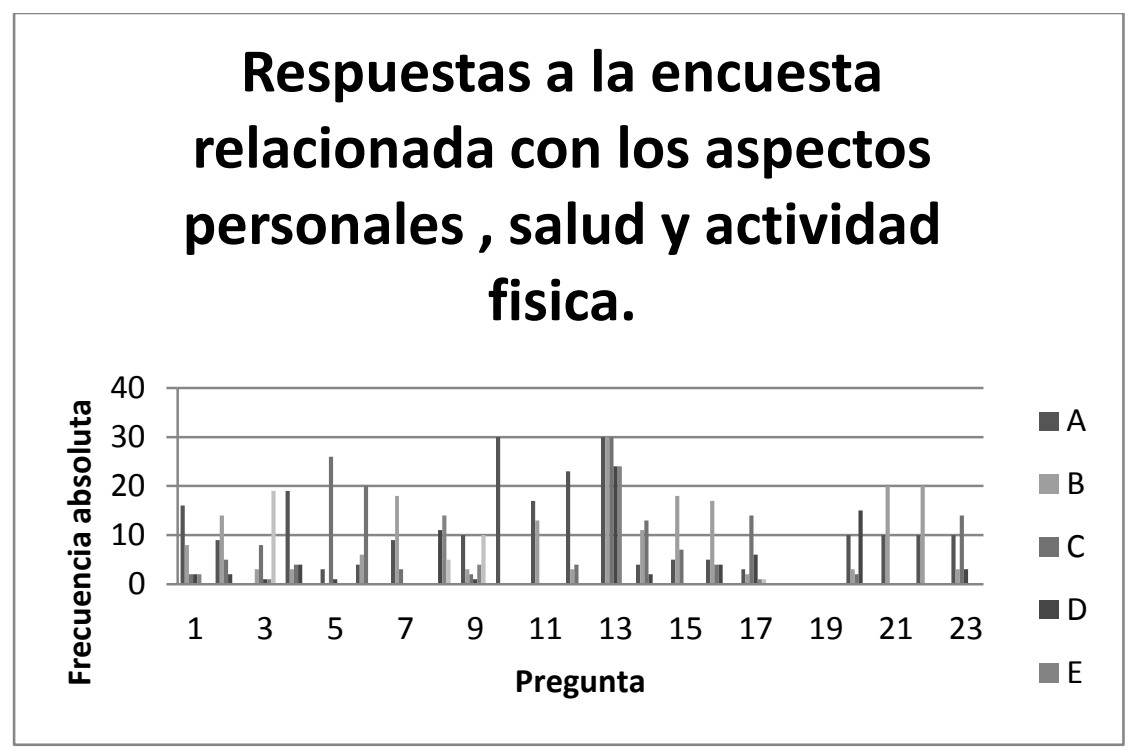

La frecuencia absoluta ubicada al lado izquierdo de la gráfica representa el número de estudiantes encuestados, la numeración inferior el número de la pregunta aplicada, y las letras de A - G ubicadas a la derecha son las opciones de respuesta de cada pregunta.

Los hallazgos revelan que más de la mitad de los encuestados viven con mamá, papá y hermanos. La mitad del grupo encuestado considera que las relaciones afectivas con su grupo familiar son buenas. La mayoría de los encuestados no presenta alguna situación agresiva o de maltrato en su casa y más de la mitad del grupo encuestado afirma que ambos padres trabajan y casi todos colaboran con las labores y responsabilidades del hogar.

El 65\% de los encuestados considera que las relaciones con los amigos y compañeros son buenas y el $60 \%$ de los encuestados afirma alimentarse bien. Casi la mitad del grupo se alimenta diariamente con las tres comidas básicas y muchos de los encuestados se alimentan con exceso de carbohidratos. El ciento por ciento de ellos no maneja dietas especiales o prescritas por el médico y el refrigerio escolar es un complemento de las tres comidas básicas para el 57\%. 
IMAGINARIOS SOCIALES FRENTE A LA CORPORALIDAD

El $77 \%$ están afiliados a una EPS; el $100 \%$ de los encuestados cuenta con los servicios públicos básicos y asisten a controles médicos el $43 \%$ más de tres veces al año. El 60\% asegura que en el último año su estado de salud ha sido bueno y más de la mitad del grupo asistió al médico en el último año a control médico.

La enfermedad más presente en los familiares de los encuestados es la diabetes y la gran mayoría de los encuestados no tiene claridad y/o confunde el concepto de actividad física, sin embargo la mayoría de los encuestados practican actividad física moderada fuera de la clase de educación física y gran parte de los encuestados practica actividad física de dos a tres veces por semana. De igual manera el $67 \%$ de los encuestados pueden acceder a espacios que facilitan la práctica de la actividad física y casi la mitad de los encuestados no se considera hábil para realizar cualquier actividad física. El $47 \%$ de los encuestados no práctica en su tiempo libre actividad física con su familia.

En términos generales, la necesidad principalmente detectada se basa en escasa participación en eventos o actividades que impliquen de manera voluntaria, repetida y constante la práctica vigorosa de actividad física, principalmente fuera del colegio.

Con respecto al Test sobre estilos de vida llamado Fantástico, los hallazgos se lograron a través del análisis de las Gráfica Nro. 2 y la Gráfica Nro. 3.

\section{Gráfica Nro. 2}

\section{Resultados Test Fantástico}




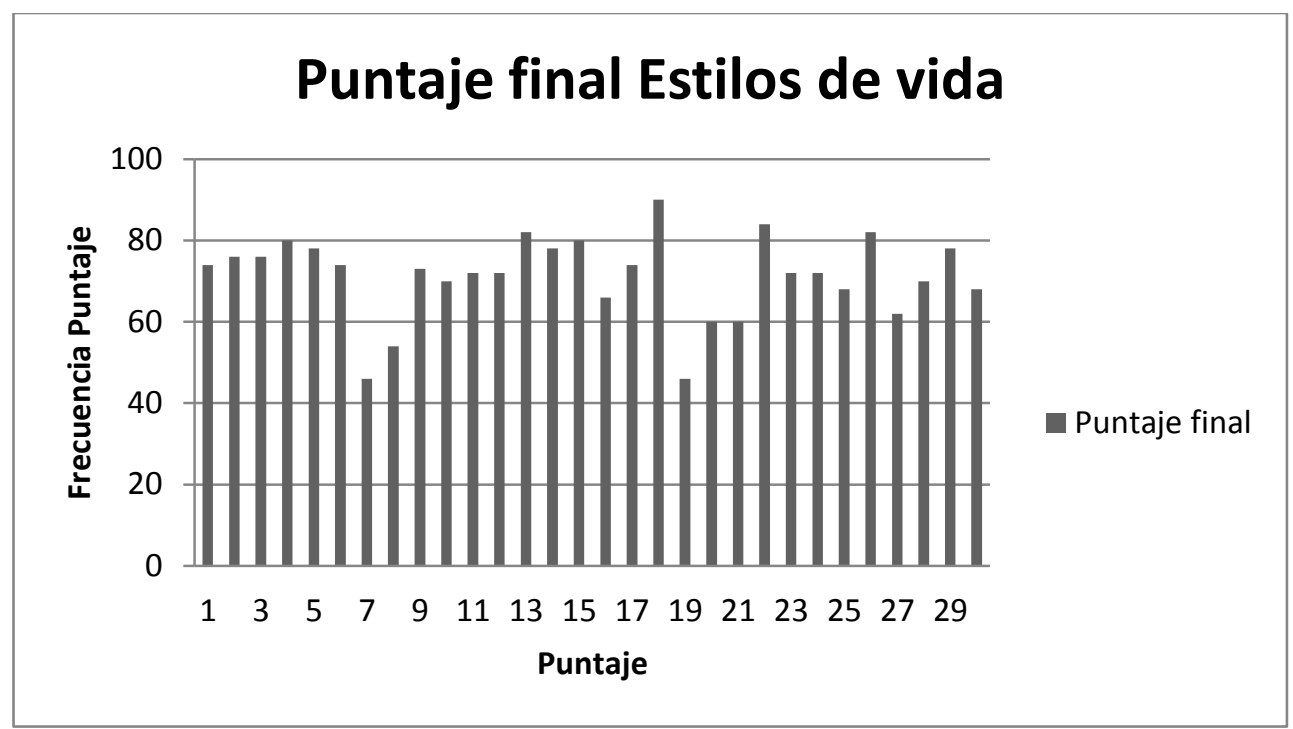

\section{Grafica Nro. 3}

Frecuencia Porcentaje Estilos de Vida

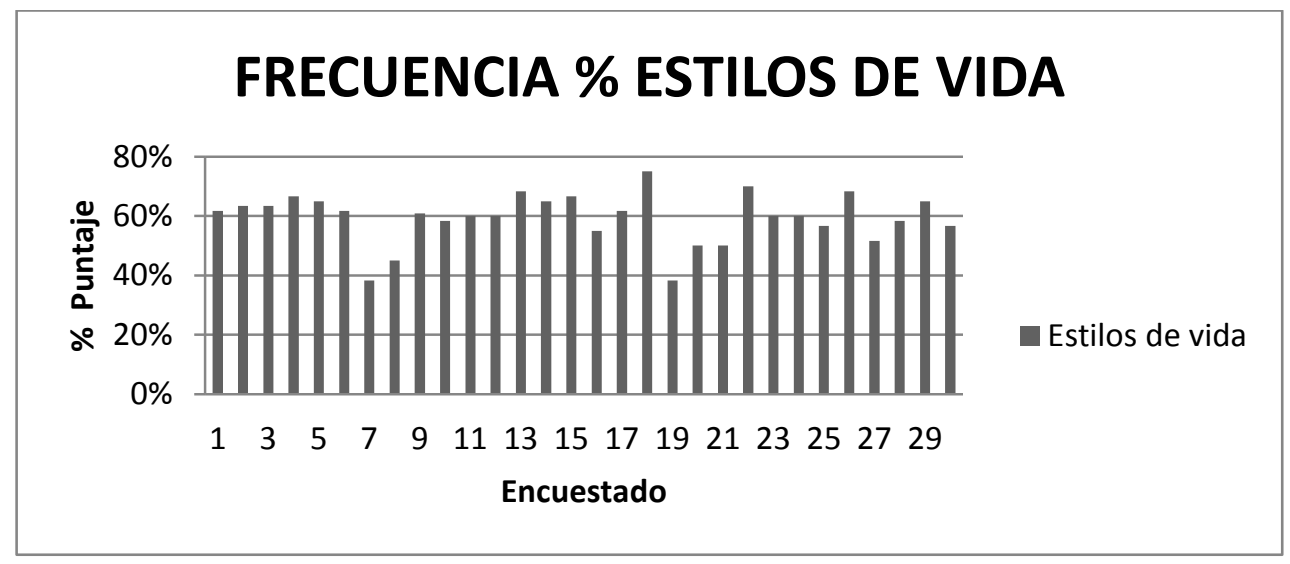

En el Anexo $\mathrm{H}$ y el Anexo I se muestran las tablas de frecuencia absoluta de Estilos de Vida y los porcentajes de los encuestados. 
IMAGINARIOS SOCIALES FRENTE A LA CORPORALIDAD

Con respecto a las gráficas Nro. 2 y Nro. 3 ninguno de los encuestados obtuvo un puntaje superior a 82 por lo tanto ninguno tiene un estilo de vida fantástico, pero se acercan a estar en el camino correcto. Doce de treinta encuestados obtuvieron puntuación superior a 73 e inferior a 84 adecuado, estas bien. Más de la mitad del grupo (16 personas) respondieron dando como resultado un puntaje entre 47 a 72 lo cual quiere decir que están algo bajo, podrían mejorar su estilo de vida. Dos personas de los encuestados están en la zona de peligro pues su puntuación fue inferior a 47.

El 70\% de los encuestados obtuvieron un puntaje óptimo en las preguntas relacionadas con alcohol y otras drogas. El 20\% de los encuestados obtuvieron solo un punto en las preguntas relacionadas con tipos de personalidad lo cual podría reflejarse con facilidad observando la manera como algunos resuelven conflictos en su cotidianidad.

\section{Análisis e Interpretación de datos Segunda Fase Grupo Focal}

La segunda fase incluyó la selección de la muestra final para el grupo focal y la aplicación de las entrevistas semiestructuradas para determinar los imaginarios sociales, los conceptos y usos de la corporalidad. Los hallazgos que se encontraron en la primera entrevista a cinco estudiantes de décimo grado se realizó en junio 3 del año 2016 e indican que la corporalidad se refiere a un imaginario en común entre los jóvenes participantes, en detalle tres estudiantes mujeres y dos estudiantes hombres. 
IMAGINARIOS SOCIALES FRENTE A LA CORPORALIDAD

La entrevista se realizó con el uso del instrumento Cuestionario de Corporalidad. Ver Anexo F. Este cuestionario permitió indagar sobre las tres categorías a saber: Imagen Corporal, Cuerpo y Movimiento y Concepto para analizar los imaginarios y decantarlos en el concepto de la corporalidad. El análisis de las respuestas incluyó la codificación de cada categoría así: Imagen Corporal IM, Cuerpo y Movimiento CM, Concepto C y la matriz que a continuación se presenta. En ella se realizó el cruce de la información asignando núcleos tématicos para obtener una interpretación de las respuestas de los estudiantes.

Tabla Nro. 1

Matriz Cuestionario de Corporalidad y Categorías

\begin{tabular}{|c|c|c|c|c|c|c|}
\hline $\begin{array}{l}\text { Sujeto } \\
\text { /Item }\end{array}$ & Cod. & Sujeto 1 & Sujeto 2 & Sujeto 3 & Sujeto 4 & Sujeto 5 \\
\hline 1 & IM & $\begin{array}{l}\text { Alimentación } \\
\text { Deporte }\end{array}$ & Alimentación & $\begin{array}{l}\text { Ejercicio } \\
\text { Aseo } \\
\text { Personal }\end{array}$ & $\begin{array}{l}\text { Cuidado } \\
\text { Auto } \\
\text {-agresión }\end{array}$ & Ejercicio \\
\hline 2 & IM & $\begin{array}{l}\text { Capacidad } \\
\text { Fisica y motriz }\end{array}$ & $\begin{array}{l}\text { No hay } \\
\text { limitaciones }\end{array}$ & $\begin{array}{l}\text { Cualidades } \\
\text { corporales } \\
\text { Ejecución } \\
\text { motriz }\end{array}$ & $\begin{array}{l}\text { Cualidades } \\
\text { corporales }\end{array}$ & $\begin{array}{l}\text { Ausencia } \\
\text { Discapacida } \\
\text { d }\end{array}$ \\
\hline 3 & IM & $\begin{array}{l}\text { Actitud } \\
\text { Positiva } \\
\text { Temperamento } \\
\text { Luchadora }\end{array}$ & $\begin{array}{l}\text { Cualidades y } \\
\text { Valores }\end{array}$ & $\begin{array}{l}\text { Aspecto } \\
\text { espiritual }\end{array}$ & $\begin{array}{l}\text { Conexión } \\
\text { espiritual } \quad \text { y } \\
\text { religiosa }\end{array}$ & Enfermedad \\
\hline 4 & IM & NR & $\begin{array}{l}\text { Pensamientos } \\
\text { Proyección } \\
\text { Diferentes }\end{array}$ & Pensamiento & $\begin{array}{l}\text { Género } \\
\text { femenino } \\
\text { comparación } \\
\text { y género } \\
\text { masculino } \\
\text { Belleza }\end{array}$ & No sabe \\
\hline
\end{tabular}




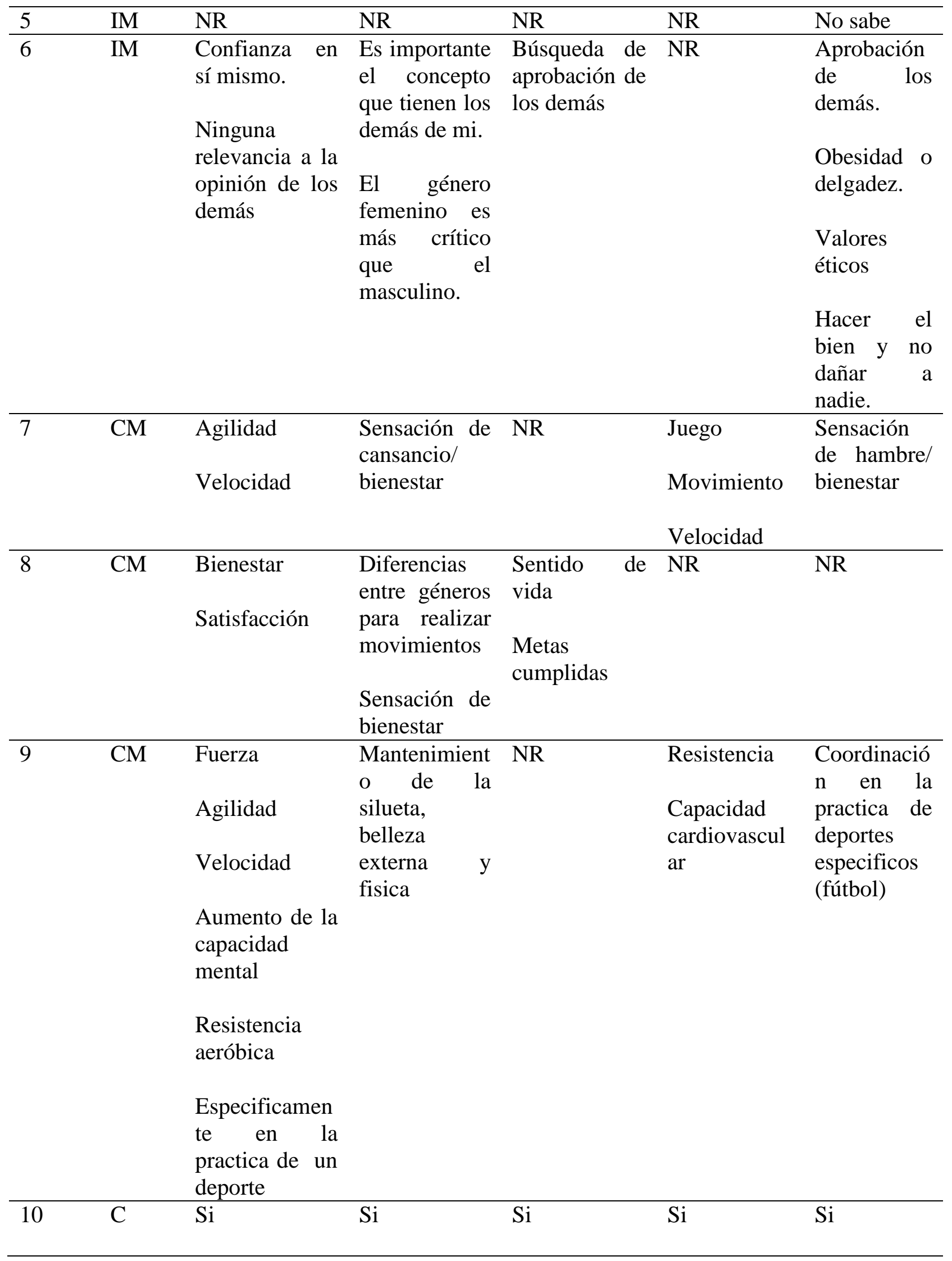


IMAGINARIOS SOCIALES FRENTE A LA CORPORALIDAD

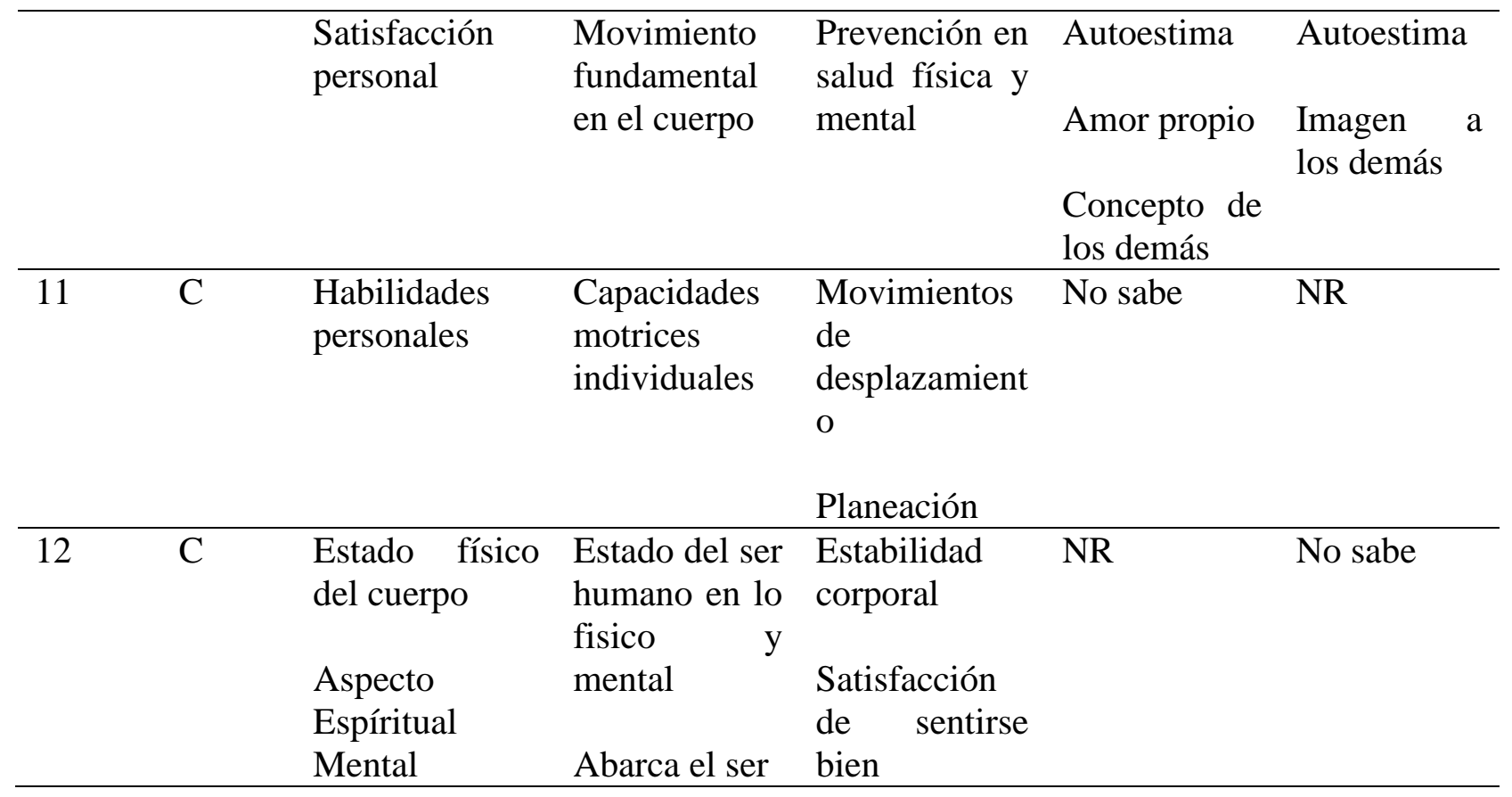

Nota: Los números corresponden a las preguntas de la encuesta Anexo F.

Teniendo en cuenta el cruce de la información de la Matriz Nro. 1., los hallazgos describen los imaginarios respecto a las categorías de Imagen Corporal, Cuerpo y Movimiento y Concepto.

En primera instancia, es evidente que los estudiantes relacionan la Imagen Corporal IM con los hábitos de autocuidado, es relevante la alimentación, el aseo personal y la práctica de un deporte o actividad física, las respuestas frente a los interrogantes ¿Qué cuidados tiene usted en relación con su cuerpo? o ¿Cómo se siente con su cuerpo? fue: “Sujeto 1. Eh comer, en hacer deporte diario, yo por ejemplo las martes y los jueves es cuando yo hago más en las noches y los sábados". También asocian la idea de autocuidado con evitar la autoagresión: "Sujeto 4. Y... cuidarse bien y no lastimarse” 
IMAGINARIOS SOCIALES FRENTE A LA CORPORALIDAD

Del autocuidado, los estudiantes revelan la importancia de contar con cualidades corporales especificas: "Sujeto 4. Satisfecho en las cualidades que el cuerpo tiene para hacer cualquier cosa” y mencionan el hecho de la ausencia de la condición de discapacidad en ellos: "Sujeto 5 y también que tengo todas mis partes y no me hace falta nada..."

En concordancia, los hallazgos de Imagen Corporal centran la opinión en actitudes, cualidades y valores. Los estudiantes con las preguntas Al mirarse frente al espejo ¿que ve usted?, ¿Cómo cree que ven su cuerpo los demás? y ¿Cómo crees que los demás ven tu cuerpo?, expresaron: "Sujeto 3 pues yo me veo como... siempre me he visto como una mujer decidida y pues siempre me he tratado de ver así. Decidida y que se cuida bastante y ya”.

Así mismo, frente a la pregunta ¿Qué tan importante es para ustedes la opinión que los demás tiene con respecto a su corporalidad?, los jóvenes expresaron diferencias entre la opinión del género femenino o masculino, respuestas como: "Sujeto 2 los hombres casi no se preocupan pero las mujeres como tenemos no se algo... jijijiji que nos hacemos sentir más inferiores que otra y queremos ser menos inferiores" dan cuenta del imaginario de los jóvenes cuyo reconocimiento de pensamientos existentes alrededor de la individualidad asociada a la condición de hombre o mujer presentan diferencias en la forma de pensar. Así mismo, la confianza en sí mismo y la opinión de los demás es relevante para los jóvenes y se percibe una diferenciación entre los actos buenos y malos cuyo comportamiento pueda perjudicar o beneficiar al otro. Siendo relevante la ética en este aspecto de los imaginarios sociales, hay respuestas como: "Sujeto 5 pues con... osea pues yo creo que... igual forma si uno se... si uno esta gordito o flaquito yo creo que las personas siempre lo van criticar a uno. Así uno esté bien o mal siempre lo van a criticar a uno. Entonces la verdad...la verdad no me importa lo que 
IMAGINARIOS SOCIALES FRENTE A LA CORPORALIDAD

piensen los demás sobre mi cuerpo sobre mí. Si yo sé que hago las cosas correctas yo siento que para mí está bien. y ... con tal de que no le esté haciendo daño a las demás personas. Pero... ya lo demás no importa"

Los hallazgos en la segunda categoría Cuerpo y Movimiento CM, ubican las cualidades fisicas motrices, la belleza exterior y el funcionamiento de los órganos de la respiración, resistencia o cardiovascular como aspectos que generan mayor relación con el movimiento y el cuerpo. Para los jóvenes es claro lo anterior en respuestas frente a la pregunta ¿qué beneficios tiene la actividad física en su cuerpo?: "Sujeto 1 Es que por ejemplo en el fútbol se ve prácticamente todo. Eh fuerza, velocidad, agilidad y pues, también hay que pensar... Es una actividad física que sirve básicamente para todo el cuerpo lo ayuda a uno a estar bien tanto físicamente como en la salud. Uno empieza a poner más resistentes los pulmones, el corazón y a controlar hasta también la respiración”

Por último, la categoría Concepto Corporal arrojó como resultados la asociación de la sensación de satisfacción con la autoestima, así como la relevancia de la opinión de los demás y la imagen que cada uno de ellos posee del estudiante, esto revierte directamente en la autoestima asociada sin duda a las habilidades motrices individuales, llama la atención que los jóvenes expresan que el concepto corporal se asocia sin duda al Ser, como esencia del ser humano. Tal lo como se expresa frente a la pregunta "¿Qué entiende usted por corporalidad?: "Sujeto 1 pues el estado fisico del cuerpo, la salud y... no solo la salud sino lo mental y lo espiritual" y el "Sujeto 2 El estado en que se encuentra un ser humano, no solo físicamente sino...en todo su ser" 
IMAGINARIOS SOCIALES FRENTE A LA CORPORALIDAD

En julio 27 de 2016 se realiza una segunda y última entrevista al grupo focal de cinco estudiantes, quiénes participaron bajo la modalidad de entrevista semiestructurada. Los siguientes interrogantes constituyeron las pregunas orientadoras para la entrevista semiestructurada del Grupo Focal. Cada una de ellas se le asignó un número y una categoría de análisis que se detallan en la Matriz Nro. 2.

1. ¿Qué cuidados tiene usted en relación con su cuerpo?

2. ¿Cómo se sienten con su cuerpo cada uno?

3. ¿Qué ven ustedes al mirarse frente al espejo?, ¿cómo creen que ven su cuerpo los demás?

4. ¿Qué tan importante es para ustedes la opinión de los demás con respecto a su cuerpo?

5. ¿Qué funciones cumple el cuerpo en la cotidianidad de cada uno de ustedes?

6. ¿Cómo siente o percibe su cuerpo durante la práctica de la actividad física?

7. ¿Qué beneficios tiene la actividad física en su cuerpo?

8. ¿Cómo se maneja este aspecto en su vida? en el trabajo, en el hogar, en la comunidad?

9. ¿Considera usted necesario mantener una buena imagen corporal?,

10. ¿Qué entiende Ud. por cuerpo?

11. ¿Pero será que dentro del cuerpo está el alma?

Matriz Nro. 2

\section{Grupo Focal Tema Corporalidad}




\section{\begin{tabular}{lllllll}
\hline Sujetos/ & Códigos & Sujeto 1 & Sujeto 2 & Sujeto 3 & Sujeto 4 & Sujeto 5
\end{tabular}}

\section{Item}

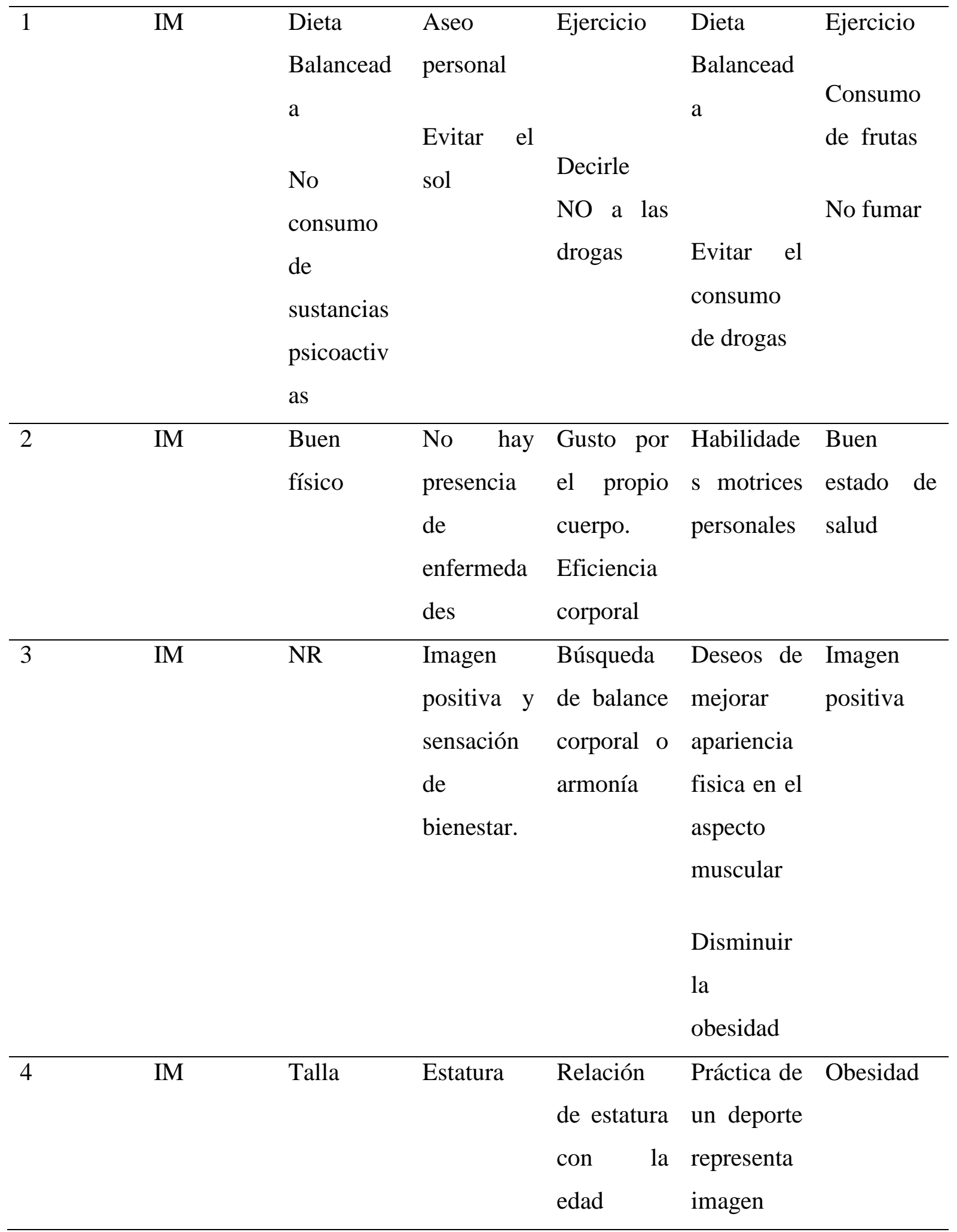




\begin{tabular}{|c|c|c|c|c|c|c|}
\hline & & & & & $\begin{array}{ll}\text { ante los } \\
\text { demás }\end{array}$ & \\
\hline 5 & IM & $\begin{array}{l}\text { Autoconce } \\
\text { pto } \\
\text { Autoimage } \\
\text { n }\end{array}$ & $\begin{array}{l}\text { Autoestim } \\
\mathrm{a}\end{array}$ & $\begin{array}{l}\text { Es } \\
\text { relevante } \\
\text { la opinión } \\
\text { de los } \\
\text { demás }\end{array}$ & $\begin{array}{l}\text { Práctica de } \\
\text { un deporte } \\
\text { influye en } \\
\text { la opinión } \\
\text { de los } \\
\text { demás }\end{array}$ & $\begin{array}{l}\text { Práctica de } \\
\text { un } \\
\text { deporte y } \\
\text { relaciones } \\
\text { de } \\
\text { noviazgo }\end{array}$ \\
\hline 6 & IM & $\begin{array}{l}\text { Fuerza } \\
\text { Velocidad } \\
\text { Resistenci } \\
\text { a } \\
\text { Agilidad }\end{array}$ & $\begin{array}{l}\text { Adaptació } \\
\text { n } \\
\text { Transform } \\
\text { ación }\end{array}$ & $\begin{array}{l}\text { Roles } \\
\text { Ocupacion } \\
\text { ales } \\
\text { Estudio vs. } \\
\text { Trabajo }\end{array}$ & & \\
\hline 7 & $\mathrm{CM}$ & Gusto & $\begin{array}{l}\text { Motivació } \\
\text { n }\end{array}$ & $\begin{array}{l}\text { Práctica de } \\
\text { un deporte }\end{array}$ & $\begin{array}{l}\text { Motivació } \\
\mathrm{n}\end{array}$ & $\begin{array}{l}\text { Cansacio } \\
\text { Desgaste } \\
\text { Motivació } \\
\text { n }\end{array}$ \\
\hline 8 & $\mathrm{CM}$ & $\begin{array}{l}\text { Beneficio } \\
\text { cuerpo y } \\
\text { salud }\end{array}$ & $\begin{array}{l}\text { Prevenció } \\
\mathrm{n} \text { de } \\
\text { enfermeda } \\
\text { des }\end{array}$ & $\begin{array}{l}\text { Adaptació } \\
\text { n al medio }\end{array}$ & Ejercicio & Salud \\
\hline 9 & $\mathrm{CM}$ & $\begin{array}{l}\text { Movimient } \\
\text { o es } \\
\text { fundament } \\
\text { al }\end{array}$ & $\begin{array}{l}\text { Determina } \\
\text { a } \\
\text { capacidad } \\
\text { de } \\
\text { actividad } \\
\text { de la } \\
\text { persona }\end{array}$ & $\begin{array}{l}\text { El } \\
\text { movimient } \\
\text { o es } \\
\text { adaptativo }\end{array}$ & $\begin{array}{l}\text { Es } \\
\text { fundament } \\
\text { al para el } \\
\text { cuerpo }\end{array}$ & $\begin{array}{l}\text { Independe } \\
\text { ncia y } \\
\text { autonomía }\end{array}$ \\
\hline
\end{tabular}


IMAGINARIOS SOCIALES FRENTE A LA CORPORALIDAD

\begin{tabular}{|c|c|c|c|c|c|c|}
\hline 10 & $\mathrm{IM}$ & $\begin{array}{l}\text { La imagen } \\
\text { externa es } \\
\text { importante }\end{array}$ & $\begin{array}{l}\text { Estereotip } \\
\text { os } \\
\text { culturales }\end{array}$ & $\begin{array}{l}\text { Imagen no } \\
\text { es solo de } \\
\text { la } \\
\text { apariencia } \\
\text { física, } \\
\text { también } \\
\text { del } \\
\text { intelecto }\end{array}$ & $\begin{array}{l}\text { Es } \\
\text { necesaria }\end{array}$ & $\begin{array}{l}\text { La } \\
\text { opinión de } \\
\text { los demás } \\
\text { es } \\
\text { relevante } \\
\text { para la } \\
\text { imagen } \\
\text { externa. }\end{array}$ \\
\hline 11 & $\mathrm{C}$ & Masa & $\begin{array}{l}\text { Ocupa un } \\
\text { espacio }\end{array}$ & Forma & $\begin{array}{l}\text { Es lo que } \\
\text { ven de } \\
\text { nosotros }\end{array}$ & $\begin{array}{l}\text { Es una } \\
\text { unidad } \\
\text { Relación } \\
\text { las } \\
\text { funciones } \\
\text { con el } \\
\text { cuerpo }\end{array}$ \\
\hline 12 & $\mathrm{C}$ & Creencias & Unidad & $\begin{array}{l}\text { Habilidade } \\
\text { s }\end{array}$ & $\begin{array}{l}\text { Funcionali } \\
\text { dad }\end{array}$ & $\begin{array}{l}\text { Espirítu } \\
\text { Alma }\end{array}$ \\
\hline
\end{tabular}

Nota: Cada pregunta se relaciona con una categoría de análisis y su codificación

Con la pregunta Nro. 1 ¿qué cuidados tiene usted en relación con su cuerpo?, la mayoría de las respuestas se centraron en el consumo de una dieta balanceada, práctica de ejercicio, aseo personal y evitar acciones que perjudiquen la salud como consumo de drogas, exposición al sol sin protección. Algunas de las respuestas indican que los jóvenes relacionan la imagen corporal con el cuidado: S1 "una alimentación balanceada, o sea dependiendo de lo que el cuerpo necesite, alimentarse de la manera (risas) alimentarse como digamos si necesita subir de peso o bajar alimentarse según la dieta que necesita” o S2 “eh pues sí uno ve también las perforaciones y todas esas, las... la cachucha por lo menos el sol es uno de los generadoras 
IMAGINARIOS SOCIALES FRENTE A LA CORPORALIDAD

de cáncer en la piel no y pues la cachucha ayuda mucho a eso, el bloqueador protegerse el bloqueador" о S5 "el no fumar pues porque eso también es muy perjudicial para la salud”

Con respecto a la pregunta Nro. 2 ¿Cómo se sienten con su cuerpo cada uno? Los hallazgos evidenciaron la relación entre sentirse bien con el buen nivel fisico y de salud, la no presencia de enfermedades y la eficacia en la ejecución de los movimientos. Sobre la idea de belleza externa, los jóvenes valoran estos aspectos como condicionantes para sentirse satisfechos con su cuerpo. Respuestas como S1 “yo me siento bien pues porque a nivel físico eh estoy bien o sea tengo un buen físico, no digamos a la belleza sino en velocidad, coordinación y todo eso”, S2 “pues yo me siento bien porque no tengo ninguna enfermedad así peligrosa o que sea que me vaya a morir o algo así no" o "S5 eh yo me siento bien con mi cuerpo es pues porque eh debido a una buena alimentación y un buen ejercicio puedo desarrollar cada actividad que me pongan y tengo muy buen estado de salud”, describen esta categorización de imagen corporal.

A la pregunta Nro.3 ¿qué ven ustedes al mirarse frente al espejo?, los jóvenes coinciden en afirmar sensaciones de bienestar e imagen corporal positiva, sin embargo hay deseos de cambiar su cuerpo ya sea en disminución de masa corporal o aumento de la musculatura. Respuestas como S3 "eh pues yo cuando me veo al espejo miro las piernas (risas) realmente porque ehh siempre quiero que haya un balance en mi cuerpo entonces si de alguna manera he anchado espalda pues necesito que mis piernas tengan la suficiente fuerza para llevar el peso corporal de mi cuerpo, entonces cada vez miro que todo esté muy balanceado es eso cuando miro al espejo que esté balanceado" o S4 "cuando yo me miro al espejo pues no se no me siento a gusto pero también me gustaría tener más masa corporal, si muscular” dan cuenta de lo anterior. 
A la pregunta Nro. 4 ¿cómo creen que ven su cuerpo los demás? los jóvenes perciben con claridad la opinión que tienen los demás como un aspecto relevante en la Imagen Corporal siendo determinante su aspecto físico en cuanto talla y estatura. Asi mismo, relacionan la estatura con la edad cronológica de cada joven. Respuestas como S1: "pues a mí la gente me ve bien flaquito porque soy alto y soy flaco entonces pero pues de igual forma me gusta como soy" revelan una contradicción entre lo que piensan los demás y la opinión de cada joven siendo relevante la primera sobre la segunda. Llama la atención que la práctica de un deporte puede ser representativo en la imagen ante los demás. Este hallazgo revela la importancia de lo anterior: S5 " yo pienso que también hay que mirar que como decía aquí mi compañero el deporte que uno practica tiene que influir mucho porque sí yo soy atletista o soy atleta o ciclista sería algo como estúpido pensar que quiero ser ancho que quiero tener mucho volumen ya que el deporte infringe como se dice o sea ehh en que a usted le exigen en una exigencia tan alta de sudar de bajar masa para que usted sea más liviano para que usted pueda tener más resistencia para que usted ehh corra más rápido para que usted sea más liviano que los demás y poder subir más rápido en las clases de ciclismo entonces si uno es ciclista no tiene que llegar a pensar q uno va a ser ancho con buenas piernas grandes va a estar marcado pero no con mucho volumen"

Al preguntar ¿qué tan importante es para ustedes la opinión de los demás con respecto a su cuerpo? las opiniones se dividen, para algunos no es relevante la opinión de los demás, S1 "Pues la verdad a mí no, no, no me afecta pues porque o sea ellos no como que de ellos no vivo, entonces no, no me influye tanto la opinión de los demás”, mientras que para otros sí influye: S3 “yo tengo muy en cuenta muchas veces las opiniones de las personas ehh yo creo y no creo o sea es como una cosa rara ahí, en la crítica constructiva porque a ti te dicen no pues podrías hacer ejercicio para que te sientas mejor, para que subas autoestima porque 
IMAGINARIOS SOCIALES FRENTE A LA CORPORALIDAD

muchas veces es baja autoestima no? y pues en mi parecer ehh si también depende mucho la persona que me lo diga, pero pues si yo veo tengo que mejorar en algo, valoro mucha esa opinión no para decir ah soy feo o algo así sino para ser algo mejor”.

En cuanto a la opinión de los demás, es necesario mencionar que tanto hombres como mujeres, lo que piense el sexo opuesto es relevante sobretodo cuando existen relaciones amorosas entre ellos, el noviazgo delata la necesidad de agradar al otro y obtener su aprobación. La respuesta del S3 "en esa parte pues yo siempre he dicho que cuando tú haces ejercicio te sientes bien, eres saludable y te ves más sexy jejeje porque en realidad es eso hay un gusto y el gusto está entre las mujeres y los hombres o si tú tienes un novio quieres que ese novio sea lindo, que sea fuerte, que sea con gen fuerte para que tus hijos sean fuertes que nosotros aun siendo muy pensantes tenemos muchos instintos, entonces si mi novia me llegara a decir alguna vez a mí que estoy mal físicamente que tengo algo que mejorar para verme más lindo pues intentaría hacer lo posible por ello" enfoca el ejercicio y el noviazgo como dos aspectos que influyen en la opinión de las demás personas respecto a un sujeto.

Frente a la pregunta Nro. 6 ¿Qué funciones cumple el cuerpo en la cotidianidad de cada uno de ustedes?, las respuestas de los estudiantes refieren la velocidad, agilidad, fuerza y resistencia. Una respuesta permitió inferir que algunos estudiantes trabajan y estudian como parte de sus ocupaciones, esta respuesta: $S 3$ “ en el trabajo, muchas veces hay personas que estudian y trabajan aún en el colegio y si necesitan un físico fuerte, un físico ágil porque muchas veces el físico influye en que Ud. pueda resistir un día de cotidianidad para Ud., para muchas personas no solamente quedarse en asiento todo el día sentado, no es estar ahí y comer y ya para muchas personas es levantarse correr pa arriba, correr pa abajo, subir, bajar estar en cualquier momento pendiente de las instrucciones que le manden, muchas personas bajar 
IMAGINARIOS SOCIALES FRENTE A LA CORPORALIDAD

bloque, cemento, eh meseriar, cosas de ese estilo y se necesita un físico fuerte para no quedar muerto y no cumplir en todo"

Los hallazgos demuestran que los jóvenes consideran que el cuerpo sufre trasnformaciones en cuanto a la actividad a la cual es sometido y de esta forma la adaptación al medio es evidente: $S 2$ "pues como dicen ellos dos el cuerpo influye en la actividad que uno realiza porque depende del trabajo, si Ud. en el trabajo no necesita estar de pie, o no necesita estar en constante movimiento pues su cuerpo se va a adaptar a eso pero después cuando le toque desarrollar otra actividad, o sea siempre hay que tener en cuenta que el cuerpo es como ehh tiene que adaptarse a la actividad que uno realice, entonces depende de q actividad uno realice entonces ahí si influye el cuerpo o que parte del cuerpo influye “

De acuerdo al conversatorio, la pregunta Nro. 7 ¿cómo siente o percibe su cuerpo durante la práctica de la actividad física?, las respuestas revelan gusto y práctica con motivación de la actividad física a pesar de la aparición del cansancio o desgaste. La motivación es una constante en la práctica de la actividad fisica, el S1 refiere "la verdad si me gusta o sea hacer ejercicio al mirarme al espejo si, o sea como de verdad no me afectan las críticas de las otras mujeres pero si me gusta sentirme bien yo misma y verme bien frente a un espejo"

La actividad física influye en la motivación de los jóvenes, sobretodo cuando se practica un deporte en rutinas establecidas, S3 "pues yo me siento muy bien en el momento de actividad física porque ya el deporte q práctico me exige un alto, muy alto rendimiento"

Respecto al interrogante ¿Qué beneficios tiene la actividad física en su cuerpo?, las respuestas coinciden en afirmar que es beneficiosa para la salud, cuerpo y salud son un solo ente y nuevamente la adaptación como condición corporal llama la atención en el análisis e interpretación de los datos. Al respecto el S1 menciona "pues, o sea cuando uno realiza 
IMAGINARIOS SOCIALES FRENTE A LA CORPORALIDAD

actividad física es bueno para la salud, realizar actividad física o tener una rutina de ejercicio es bueno para nosotros acostumbrarnos a lo que viene en un futuro, para que nuestro cuerpo se adapte a las actividades que realizamos, entonces digamos si mi cuerpo desde ya tiene un una buena rutina física más adelante cuando yo tenga cierta edad, mi cuerpo no va sufrir digamos de que a muchas personas les da osteoporosis a una edad adelantada por no realizar ejercicios, entonces si uno realiza actividad física esas enfermedades se pueden o no presentar o presentarse mucho más adelante”

Durante el conversatorio la afirmación del profesor investigador “Consideran que el movimiento es parte fundamental del ser humano” permite la pregunta: ¿cómo se maneja este aspecto en su vida? en el trabajo, en el hogar, en la comunidad?. Los jóvenes afirman en su totalidad que es un aspecto relevante en la vida del ser humano, S1: "pues el movimiento es un aspecto fundamental para cada persona. Para tanto para caminar como también para hacer las actividades q uno está acostumbrado a realizar. eso siempre como lo dije y como lo sigo repitiendo depende la el adapta...la...ósea como el cuerpo se adapte a la actividad que uno realice porque si tú siempre vas a estar sentado entonces no influye mucho el movimiento en tus piernas pero si en tus manos, en tus brazos, en tu cabeza y mientras que si tu digamos trabajas en un supermercado influye más caminando o hablando o atendiendo a la gente, entonces depende de la actividad que uno realice para poder o sea como para poder mirar si el movimiento es importante o no en la actividad que uno realiza”. La capacidad de adaptación del cuerpo es determinante en la ejecución de los movimientos según la opinión de los jóvenes.

Con respecto a la pregunta Nro. 10 ¿considera usted necesario mantener una buena imagen corporal?, los jóvenes confirman que es necesario para ser aceptado de acuerdo con las exigencias actuales de belleza exterior y los estereotipos que cada cultura posee, al respecto el S1 
IMAGINARIOS SOCIALES FRENTE A LA CORPORALIDAD

afirma "en esta sociedad sí, con la crítica de las personas sí para el trabajo también en la escuela sí, para la sociedad como tal hay que tener una buena imagen corporal, si tú eres para las mujeres si tú no tienes senos, no tienes cola entonces no vas a ser vista por los demás no vas a ser buena para nadie a menos de que tengas otra destreza, otra habilidad, pero para esta sociedad si hay que verse bien corporalmente”. Sin embargo, la discusión gira en torno que la imagen no solo se relaciona con la apariencia fisica o externa, también con el desarrollo de las habilidades cognitivas y emocionales de cada quién, el S3 respondió “ eh es que yo hago referencia también a que como $U d$. piensa su mente también es parte de su cuerp, usted que le gana tener un cuerpo estilizado muy bonito si por dentro allá muy al fondo es no le ejercita, el cerebro también es un músculo, el cerebro también se ejercita en el cerebro se genera también tensión entonces si no por decirlo así si no ejercitamos en totalidad el cuerpo el cerebro, nuestros músculos en sí no vamos a tener el cuerpo y la imagen perfecta por decirlo así porque si lo hacen con una persona, ustedes que harían, ustedes niñas que harían con un novio lindo pero tonto que no sabe nada?

A la pregunta Nro. 11 ¿qué entiende Ud. por cuerpo?’, los estudiantes coinciden en afirmar que es la presencia de una masa que ocupa un espacio con forma definida. El S3 cuestiona "pero entonces el cuerpo ¿debe tener una forma? ¿sería como una forma? o sea según la ciencia y según lo que yo veo es como la unión de los sistemas, de los músculos y de todo lo que conforma el cuerpo más la masa que ocupa. O sea digamos es todo lo que nosotros manejamos para mostrarnos ante la sociedad"

Y con respecto a la pregunta ¿pero será que dentro del cuerpo está el alma?, los estudiantes afirman que el cuerpo no es solo materia, tambien se refieren a la presencia de sentimientos o energía. En palabras del S4 “Ahí también esta lo sentimental, lo espiritual”; pero 
IMAGINARIOS SOCIALES FRENTE A LA CORPORALIDAD

realizan la salvedad que esa idea depende de las creencias personales, al respecto el S3 afirma: “pues profe eso también depende de las creencias, ¿no? Porque sí yo creo en Dios sé que hay un espíritu, y que mi cuerpo es un... como una cárcel, como un encierro para mi espíritu. Pero si tú crees en Buda, ya es otra cosa. Si eres ateo entonces no crees nada, crees que somos aquí... y ya se muere todo y se acabó. Es también depende de las creencias”,

Así mismo, el concepto de cuerpo se relaciona con el desempeño y las habilidades de cada quién, es decir con el movimiento que pueda realizar el mismo cuerpo: $S 2$ " A mí mismo porque son nuestras habilidades y destrezas. A mí mismo porque con mi cuerpo me muestro yo. Muestro lo que yo soy”. El cuerpo representa una unidad en el imaginario social de los jóvenes. 


\section{Resultados}

Los imaginarios sociales de la corporalidad diferenciada en las tres categorías de análisis, representaron para los jóvenes la existencia tanto de las creencias sociales respecto a las construcciones colectivas de la imagen corporal, el cuerpo ligado al movimiento y el concepto corporal como del imaginario individual contextualizado en el micromundo de cada sujeto.

Inicialmente, los resultados de las necesidades del estilo de vida señalaron la presencia de la familia, las condiciones de salud física y alimentación necesarias para los jóvenes. Se revelaron tendencias a la actividad física como inicio de la corporalidad. Se encontró claridad en el imaginario de los jóvenes respecto a la incorporación de los conceptos corporales externos, la apariencia física y estereotipos ligados a la cultura y aprobación del otro como existencia de la belleza externa y estética. Sin embargo, uno de los resultados más interesantes se relaciona con la aprobación colectiva de estándares de belleza válidos socialmente pero ligados al crecimiento intelectual y cognitivo de las personas.

Así mismo, los resultados arrojaron condiciones de poca vulnerabilidad en la población participante en esta investigación y necesidad de practicar una actividad fisica fuera de la institución educativa.

Los resultados en el estilo de vida y la identificación de cada uno de los adolescentes, permitieron realizar un sondeo de las condiciones socioeconómicas de la población participante y la influencia que éstas pueden presentar en los imaginarios sociales. 
IMAGINARIOS SOCIALES FRENTE A LA CORPORALIDAD

Las preguntas cerradas del Test y la Encuesta arrojaron resultados concisos respecto a la presencia de la familia en la vida de los jóvenes, los hábitos de alimentación y la asistencia a los centros médicos y controles de crecimiento y salubridad.

Los resultados de las entrevistas y Grupo Focal permitieron establecer claras diferencias entre los significados de imagen corporal, movimiento y concepto corporal. Las opiniones de los jóvenes reflejan asociación de los imaginarios como construcciones sociales de realidades humanas a partir de las preguntas que indagaban sobre imagen corporal. Es claro, para el imaginario colectivo que la imagen corporal parte de hábitos de autocuidado instaurados desde la cultura y patrones destinados desde las pautas de crianza con fuertes lazos sociales y colectivos.

Por otro lado, los resultados de la categoría de análisis del cuerpo y movimiento relacionan la adaptación como una caracteristica propia de la condición humana y plenamente reconocida por los jóvenes, estos resultados permiten afirmar que el cuerpo es una unidad conformada por elementos físicos y espirituales que llevan al movimiento y libertad, por ende a la corporalidad.

Los resultados en este aspecto tienen que ver con el crecimiento físico, mental y espiritual de cada quien y el reconocimiento del movimiento como un aspecto transversal del crecimiento humano y la corporalidad.

En la categorización del concepto corporal, los resultados significativos relacionan el SER como esencia de la existencia humana, las opiniones de los jóvenes van del concepto de autoestima y autodeterminación, sin embargo, el reconocimiento y la presencia del otro supone que la etapa de la adolescencia representa un momento crítico del ser humano para la corporalidad, ésta ligada a los valores morales y éticos, la presencia del otro y la alteridad 
IMAGINARIOS SOCIALES FRENTE A LA CORPORALIDAD

dentro de la convivencia humana y el establecimiento de bases firmes para el joven que debe definir su personalidad y rol en la sociedad. 


\section{Discusión}

La existencia de significaciones colectivas constituye uno de los resultados más importantes en esta investigación, los jóvenes generan imaginarios a partir de cada una de sus experiencias y de las realidades que les rodea bajo un ambiente social y cultural. Al respecto la afirmación de Castoriadis (1997) es evidente en los resultados puesto que los adolescentes son capaces de recrear situaciones y realidades humanas a través del imaginario social para instituir, transformar y conferirle sentido a los acontecimientos.

En este orden de ideas, los imaginarios sociales frente a la corporalidad de los estudiantes de grado décimo del colegio Leonardo Posada Pedraza IED surgen a partir de la imagen corporal y los diferentes núcleos temáticos que las discusiones de los jóvenes provocaron frente al debate entre lo instituido y lo instaurado.

Los imaginarios sociales construyen e interpretan realidades humanas a partir de la imagen corporal y sus diferentes significados. Pero, ¿cuáles significados son los que constituyen los imaginarios de la corporalidad a partir de la categorización de la imagen corporal?

Independientemente del género, los y las adolescentes parten del principio de materia cuya base es la constituyente del cuerpo, esto es instituido e instaurado por ellos mismos. Es necesario cuidar, alimentar, asear, ejercitar, mantener ese cuerpo humano desde la dimensión motriz, ejecutoria, funcional, visceral. Este aspecto, resulta de mucha importancia para ellos pues tanto la alimentación como la dieta balanceada generan en ellos un imaginario que no se 
IMAGINARIOS SOCIALES FRENTE A LA CORPORALIDAD

puede obviar. Ligado a esto, la funcionalidad de cada segmento corporal irá poco a poco constituyendo la imagen corporal que redunda en el imaginario y su construcción.

Esa construcción implica el aspecto físico y también el emocional, los jóvenes resaltan estos aspectos pues consideran importantes no solo el hecho de mantener el cuerpo desde un aspecto holístico y de alteridad, sino también el sentido del ser y la existencia humana. Estas dos características del imaginario social ligado a la imagen corporal (para dar cuenta de la corporalidad) dan luces sobre la necesidad imperante del joven de fortalecer las cualidades,el temperamento, el cáracter, los valores, diferenciar los actos buenos de los malos, sus consecuencias y el valor del Ser, una dimensión filosófica muy importante en el concepto de corporalidad.

En este aspecto, el joven discute y reconstruye los imaginarios a partir de su yo individual pero sin obviar la existencia del otro. Resulta que para ellos, la opinión, visión y sentimientos que los otros puedan poseer respecto a su imagen corporal es de importancia y a pesar de las afirmaciones de andar su camino sin importar la opinión del otro, se percibe cómo los jóvenes les interesa e importa la opinión del otro, su otro y la imagen que posee de él o de ella.

La discusión gira en torno como un imaginario social fuertemente constituido es el relacionado con la práctica de un deporte y cómo la habituación y dominio del mismo logran generar en ellos sentimientos de seguridad, autoestima y autoconfianza. Una practica meramente social, más no indivual. Esto debido al desarrollo y mejoramiento de la capacidad motriz, intelectual, emocional que la práctica de un deporte puede desencadenar en un adolescente cuyo crecimiento muscular y óseo es evidente. Parece ser, que la talla y estatura es considerada de importancia para ellos. 
IMAGINARIOS SOCIALES FRENTE A LA CORPORALIDAD

Otro aspecto para la construcción de los imaginarios a partir de la imagen corporal surge de la preocupación explícita de los adolescentes para prevenir enfermedades, reconocer la condición de discapacidad, el abuso del cigarrillo y consumo de drogas o sustancias psicoactivas que no sólo perjudican el funcionamiento motriz del cuerpo, sino genera condiciones de daño irreparable en las funciones cognitivas, emocionales y de estabilidad psiquica de quienes arriesgan su bienestar en estas prácticas.

En relación con esto, sin duda, los jóvenes parten de la imagen como unidad constituyente de lo imaginario. Fue evidente a lo largo del análisis de los datos, la identificación de cada joven como sujeto individual ajeno a la realidad del otro, pero ligado a la diferenciación del otro. Pedemonte (2008) lo definió como lo que se designa como 'yo' y es formado a través de lo que es el otro — en otras palabras, de la imagen en el espejo-. Es la forma primitiva de pensamiento simbólico. (p.1)

Concluyendo, la imagen corporal diferenciada del autoconcepto o esquema corporal es una entidad transformadora y determinante de los imaginarios sociales de la corporalidad puesto que implica la mirada individual y colectiva de un grupo de jóvenes que constituyen unos saberes, opiniones, sentimientos y creencias alrededor de la existencia del ser como algo corporeo y trascendental en la vida humana. En algún momento, del análisis de los resultados la conceptualización de la belleza externa medida por los estereotipos inclinó este aspecto hacia suponer que los jóvenes desean un cuerpo esbelto, pero los resultados finales de la categoría Imagen Corporal confirman que el interés es holístico, los jóvenes buscan belleza exterior e interior, desarrollar y aumentar la capacidad del cuerpo y trascender en la existencia propia y del otro. 
En este orden de ideas, la categoría Cuerpo Movimiento es intrínseca a la idea de que la corporalidad es cuerpo y libertad. Los jóvenes parten de las ideas y pensamientos que el movimiento es parte inherente del cuerpo y éste a la vez provoca la actividad física en cada sujeto. El movimiento de por sí, no sólo es un aspecto motriz para los estudiantes. Representa dentro de los imaginarios la base para el desarrollo e incremento de las cualidades físicas de resistencia, fuerza, velocidad y le añaden una característica particular a la posibilidad del movimiento.

Los jóvenes afirman que el movimiento es adaptativo a las condiciones del medio que rodea a la persona y esa adaptabilidad proporciona libertad puesto que le brinda independencia y autonomía. Al respecto, el movimiento se sirve del cuerpo, es entonces cuando el sujeto observa las cosas exteriores con su cuerpo pero a su cuerpo no lo observa, ya que para que esto necesitaría un segundo cuerpo. Retomando a Ferrante, C. (s.f.) quién afirma: "en cuanto ve o toca el mundo, mi cuerpo no puede, pues, ser visto ni tocado" (p.5). El movimiento cobra importancia en este reconocimiento del cuerpo.

Así mismo, el movimiento del cuerpo implica corporalidad en el sentido amplio de lograr libertad. Es evidente que los jóvenes imaginan que el cuerpo, el movimiento, la independencia y autonomía que se logra no se puede desligar del concepto de motivación. Imaginariamente la motivación alimenta la libertad de cada quién puesto que por medio de ésta el sujeto realiza y ejecuta con una sensación de bienestar y felicidad movimientos que repercuten en la capacidad de decicir y responder por sus actos. En este sentido, los jóvenes afirman que las acciones que realizan a partir del movimiento del cuerpo pueden generar confort, salud física y mental, prevenir enfermedades y obtener un beneficio cuerpo y salud. 
IMAGINARIOS SOCIALES FRENTE A LA CORPORALIDAD

La relación beneficio cuerpo y salud explica el planteamiento de Merleau- Ponty (Citado en López Saénz, M. 1996) quién afirma que el cuerpo a través de la corporeidad establece relaciones de conocimiento del otro y del diálogo; es evidente que para los jóvenes la capacidad de movimiento del cuerpo les permite la libertad, libertad de dialogar consigo mismo y con el otro en reconocimiento de un diálogo cuyo lenguaje y expresividad se fundamenta en la intersubjetividad transcendental.

Retomando el aporte de Merleau- Ponty quién expone la intersubjetividad bajo el concepto filosófico de la carne o reversibilidad, solamente el sujeto se caracteriza "siempre mediante metáforas e imágenes que expresan duolicidad: dentro y fuera, anverso y reverso, identidad y diferencia, sensación e intelección, yo y otro, etc.” (p.225). Así se analizó en los hallazgos de las respuestas de los encuestados cuyos imaginarios y conceptos sobre la corporalidad implican la presencia del otro y el dinamismo que se genera en cada uno de estos grupos y relaciones humanas. En esta discusión es claro que la afirmación del cuerpo como procurador de la corporalidad es evidente.

Finalmente, la corporalidad es cuerpo y libertad fundamentada desde una base filósofica puesto que la reflexión de cada uno de los jóvenes a través de los imaginarios revelan la base fenomenológica del cuerpo. Para los jóvenes el cuerpo y el movimiento no solo son dos entidades observables, medibles o palpables. Tal como lo plantea Merleau-Ponty, desde la fenomenología de la existencia corpórea, el cuerpo es el medio de nuestro ser hacia el mundo. Estas ideas fueron observables en los jóvenes del grado décimo del colegio Leonardo Posada. Es conveniente, explorar con los jóvenes mayores 
IMAGINARIOS SOCIALES FRENTE A LA CORPORALIDAD

comprensiones relacionadas con las ideas del ser a través del cuerpo, el movimiento, la libertad y la trascendencia del ser en la existencia humana.

Comprender los imaginarios sociales frente a la corporalidad de los estudiantes de grado décimo del Colegio Leonardo Posada Pedraza I.E.D, significó discutir alrededor de la tercera y última categoría de análisis denominada concepto corporal para establecer relación con la afirmación: la adolescencia fundamento de la corporalidad.

El concepto corporal contibuye al imaginario social de la corporalidad porque los jóvenes asocian y fundamentan autoestima y amor propio de acuerdo con el concepto de los demás. Ratificaron la importancia de sentir satisfacción personal en la ejecución de movimientos y en el cuidado personal de su cuerpo a través de la prevención en la salud física y mental.

Así mismo, el concepto corporal se fundamenta en esta etapa de la adolescencia cuyas características definida por la auto determinación e independencia, establece las bases de autoestima pero con infuencia de la imagen que se percibe de los demás. En este sentido, para los jóvenes y adolescentes del grado décimo del colegio en mención, son relevantes la asociación y conceptualización de las habilidades personales con las capacidades motrices individuales.

Las habilidades y capacidades mayores determinan los movimientos de desplazamiento para ellos y esto redunda en el concepto corporal, siendo motivante en la conformación de esta entidad. Los imaginarios sociales respecto al concepto involucran la planeación, el estado físico del cuerpo, en este aspecto, teniendo en cuenta las características de la etap de la adolescencia cuya capacidad cognitiva y pensamiento hipótetico permiten medir el estado y bienestar físico del cuerpo. Para ellos y ellas el aspecto espiritual y mental determinan el estado del ser humano y abarca el ser dando estabilidad corporal. 
IMAGINARIOS SOCIALES FRENTE A LA CORPORALIDAD

Es claro que el cuerpo ocupa un espacio, es perceptible a los sentidos propios y ajenos, el concepto corporal ocupa un espacio de reflexión filosófica, es lo que piensa y abarca el ser. "Estabilidad corporal de nosotros" en palabras de los adolescentes. No en vano, se puede afirmar que la adolescencia es la base de la corporalidad puesto que en esta etapa de crecimiento físico y cognitivo las personas establecen las relaciones de las funciones del cuerpo con las habilidades y capacidades individuales corpóreas.

Esta relación ocupa un espacio, como ya se habia mencionado, pero no sólo un espacio físico, nuevamente el sentido filosófico facilita la comprensión del cuerpo como una entidad que posee "masa" en palabras de los jóvenes y relaciona una unidad con las funciones del cuerpo, sin obviar las creencias sobre la existencia del alma y el espirítu. Aspectos trascendentales en la determinación de la personalidad de los y las jóvenes que en esta etapa de transición a la adultez reconocen las entidades de cuerpo y alma determinados por los imaginarios sociales.

Con la discusión de los resultados, se comprobó el pensamiento de Jacques Lacan al referir la adolescencia con el encuentro de la corporalidad en el estadio del espejo (Lacan, 2009, p.99), son claras las identidades e imaginarios alrededor del concepto del cuerpo como algo real, imaginario y simbólico y de varias significaciones.

Finalmente, los imaginarios de los adolescentes alrededor del concepto corporal permitieron corroborar la afirmación de Rocha (2011) que liga la adolescencia del estadio con la corporalidad. Para este autor y como resultado de la discusión de esta investigación, es evidente que cada sujeto posee una representación de su propio cuerpo, ésta se transforma a lo largo de la vida y siempre hará parte de su vida. En concordancia del concepto corporal que un 
IMAGINARIOS SOCIALES FRENTE A LA CORPORALIDAD

joven posea depende en gran medida la corporalidad e imaginarios que generen aceptación o no de esas representaciones. 


\section{Conclusiones, Aportes y Recomendaciones}

Los estudiantes de grado décimo del colegio Leonardo Posada Pedraza se encuentran en una edad relevante para la toma de decisiones, pero al mismo tiempo afloran los intereses por encontrar en el ejercicio una motivación para forjar su personalidad.

La imagen corporal adolescente debe ser un impulsador y motivador pedagógico que propicie el desarrollo de los procesos de pensamiento social, donde los docentes de educación física, ética y valores se ven como los primeros respondientes de asegurar que el cuerpo se manifieste e interprete de la manera más justa y positiva en el pensamiento y rol humano.

En cuanto a la salud se refiere, este es uno de los temas que a nivel nacional e internacional se configura como de especial interés en la sociedad actual. Un gran número de muertes provienen por problemas en este aspecto, así como también por llevar estilos de vida poco saludables. Sin duda, la modificación de estos hábitos hacia conductas que permitan superarlos, contribuirían a una mayor calidad de vida en la sociedad y a menores gastos en salud. Estos hábitos empiezan a crearse en los niños (as), afianzándose en la adolescencia y perdura en la adultez, donde ya resulta muy difícil modificarlos.

Desde el área de educación física se puede contribuir a que la educación no pierda de vista que sus sujetos también "son" cuerpos y movimientos. Su individualidad y su sociabilidad se construyen desde el propio cuerpo y la aceptación del mismo. Para lograr esto es crucial tener en cuenta que en la acción los sujetos también "son" inteligencias, emotividad, compromiso. 
IMAGINARIOS SOCIALES FRENTE A LA CORPORALIDAD

Otra alternativa de cambio, es la que plantea Cullen (1997), cuando recomienda que al enseñar se tengan en cuenta algunos de los sentidos e imágenes sobre el cuerpo y que circulan en la cultura, como una manera de comprender lo corporal, al igual dicha comprensión debe ir atada al discurso de las ciencias con relación con la Educación Física.

Desde la clase de Educación física se dispone de diversos medios útiles para ayudar al adolescente a aceptar y valorar sus propias características personales y corporales sin caer en un excesivo culto a su imagen externa, ni en el menosprecio de la misma, así mismo en esta clase de educación física se promueve la práctica del ejercicio y la importancia de realizar actividad física para mejorar la salud, mantener estados de ánimo estables, ser más asertivos en la toma de decisiones, actuar con precisión en las diferentes circunstancias que el entorno presenta.

La mayoría de los imaginarios de los estudiantes de grado décimo del Colegio Leonardo Posada Pedraza frente a la corporalidad, están ligados a lo estético y los estereotipos de belleza impuestos por la sociedad. Por tal motivo es importante resaltar las demás cualidades y capacidades del ser humano como tal; sus virtudes y función del cuerpo en movimiento como aspecto necesario en la vida.

A través del movimiento se relacionan de distinta manera las personas dándose paso a la apertura y a las experiencias corporales. De tal manera se podría afirmar que son el movimiento y la actividad física efectivos elementos generadores de calidad de vida desde el ámbito personal y social ya que favorece así en múltiples aspectos culturales y psicológicos de la condición humana tales como la solidaridad, la compasión y la autoestima entre otros. 
IMAGINARIOS SOCIALES FRENTE A LA CORPORALIDAD

La necesidad de promover el cuidado de sí mismo mediante la actividad física para mejorar los estilos de vida se hace necesaria en los estudiantes de grado décimo del Colegio Leonardo Posada Pedraza y desde cualquier área del conocimiento se puede contribuir con esta intención, mas sin embargo hay falencias que son más visibles en las clases de educación física, en la cual se evidencia actitudes tanto positivas como negativas frente a su corporalidad, relacionadas con el movimiento y el control de su propio cuerpo, la destreza, la expresión y fluidez en la ejecución de algunos movimientos complejos y en las prácticas de algunos ejercicios y deportes convencionales y no convencionales, entre otras actividades.

Los mayores factores de influencia en los imaginarios de corporalidad y bienestar de los adolescentes corresponden a la influencia de la globalización del consumo, introducido a través de los medios de comunicación más frecuentados y preferidos en su tiempo libre los cuales son; la televisión, las TIC (Tecnologías de la Información y de la Comunicación) como la Internet que con sus múltiples alternativas informativas como programas y sobre todo películas de acción afirmen en el pensamiento del futuro adulto, la representación perfecta e igualitaria de la belleza reflejada en la negación rotunda de la obesidad y al mantenimiento de la proporción exagerada de los atributos sexuales. Por lo tanto la imagen corporal del adolescente debe ser un impulsador y motivador pedagógico que asegure personas con una actitud crítica pero a la vez real y capaz de accionar el cuerpo en la multiplicidad de las relaciones personales desarrolladas en el mundo y que propicie un contexto de bienestar y salud asumidos desde su propio yo con responsabilidad y criterio de autocuidado. 


\section{Referencias Bibiográficas}

Aguayo Rousell, Hilda B. (s.f). Medios de comunicación y corporeidad. Representaciones Sociales de los Educadores Físicos. Recuperado en abril 22, 2017 de http://www.comie.org.mx/congreso/memoriaelectronica/v09/ponencias/at06/PRE117881 8360.pdf

Albaitero, M., (2002). Cornelius Castoriadis: sus conceptos. Recuperado de http://148.206.107.15/biblioteca_digital/capitulos/21-524ith.pd

Almonacid, A., (2012). La educación física como espacio de transformación social educativa: perspectivas desde los imaginarios sociales y la ciencia de la motricidad humana. Estudios Pedagógicos. Recuperado de http://www.scielo.cl/scielo.php?script=sci_arttext\&pid=S0718- 07052012000400010

Casas, I., (1999). La nueva epidemia del culto al cuerpo: Anorexia, Vigorexia, Bulimia y otros trastornos. Prevención desde la familia y la escuela. Técnica del área de Salud del INAM. Recuperado de http://www.madrimasd.org/cienciaysociedad/ateneo/dossier/alimentos_funcionales/navarr a/inam.htm

Castoriadis, C., (2006). Figuras de lo pensable. México: Fondo de Cultura Económica 
IMAGINARIOS SOCIALES FRENTE A LA CORPORALIDAD

Cisneros María E. (2011). Individuo e Imaginario en la obra de Cornelius Castoriadis. Tesis de Maestría en Filosofía y Ciencias Humanas. Universidad de Venezuela. Caracas.

Revista Digital (s.f.). Constituye y reconstituye en el mundo de la vida cotidiana. Recuperado de http://www.efdeportes.com/efd150/la-corporeidad-un-imaginario-que-se-instituye.htm

Ferrante, C., (2008). Corporalidad y temporalidad: fundamentos fenomenológicos de la teoría práctica de Pierre Bourdieu. Nómadas. Revista Crítica de Ciencias sociales y Jurídicas, 5

Fondo de las Naciones Unidas para la Infancia UNICEF, (2002). La adolescencia: Una Etapa Fundamental. Nueva York. Recuperado en abril 25, 2017 de https://www.unicef.org/ecuador/pub_adolescence_sp.pdf

Franco, A., Oliveto, G., Gómez, M., (2010). La construcción del cuerpo; la constitución subjetiva en el campo de los problemas del desarrollo. Revista Carta Psicoanalítica. Recuperado de http://www.cartapsi.org/spip.php?article63

Gallo, L., (2006). El ser corporal en el mundo como punto de partida en la fenomenología de la existencia corpórea. Pensamiento Educativo. Recuperado de http://www.pensamientoeducativo.uc.cl/files/journals/2/articles/301/public/301-706-1PB.pdf 
Hurtado , D. (2004). Reflexiones sobre la teoría de imaginarios. Universidad del Cauca. Colombia.

Jaramillo, D., (2010). La corporeidad: un imaginario que se instituye, constituye y reconstituye en el mundo de la vida cotidiana. Revista digital. Recuperado de http://www.efdeportes.com/efd150/la-corporeidad-un-imaginario-que-se-instituye.htm

Le Breton, David (2002). La sociología del cuerpo. Editorial Nueva Visión. Buenos Aires. Recuperado en abril 23, 2017 de Argentina.http://www.bioenergeticalatam.com.ar/docus/LeBreton.pdf

López Calderón, G. y León Ramírez A.(2013). Imaginarios Sociales de Mujeres estudiantes de Educación superior en Bogotá frente a su formación profesional. Universidad Pedagógica Nacional. Bogotá. Colombia. Recuperado en abril 22, 2017 de http://repositorio.pedagogica.edu.co/xmlui/bitstream/handle/123456789/454/TE16623.pdf; sequence $=1$

López Saénz, M. (1996). La fenomelogía existencial de M. Merleau-Ponty y la sociología. Universidad de La Rioja. Recuperado en abril 23, 2017 de: https://ddd.uab.cat/pub/papers/02102862n50/02102862n50p209.pdf 
IMAGINARIOS SOCIALES FRENTE A LA CORPORALIDAD

Orientación Educación Física. Educación Física y Corporeidad (s.f) Recuperado en abril, 22, 2017, de https://bibliografiaeducacion.files.wordpress.com/2012/11/educacion-fisica-ycorporeidad-4.pdf

Pedemonte, A., (2008). Lo Real, lo Imaginario y lo Simbólico. Lo Imaginario y el Concepto del Otro. La audacia de Aquiles. Recuperado de https://aquileana.wordpress.com/2008/04/27/psicoanalisis-jacques-lacan-lo-real-loimaginario-y-lo-simbólico-lo-imaginario-y-el-concepto-del-otro/

Quiceno Gil, L. C., Zapata Pérez, L. M. y Pulido Varón, H. S. (2016). Imaginarios sociales de 27 jóvenes de grado 11 sobre Medellín la más educada en una institución educativa del nororiente de la ciudad: Institución Educativa Ramón Múnera Lopera. Revista Poiésis, 109-120. Recuperado en abril 22, 2017 de http://www.funlam.edu.co/revistas/index.php/poiesis/article/view/2098/1605

Rocha, E., (2011). Adolescencia, corporalidad e inserción social. Anuario de investigación. Recuperado de http://148.206.107.15/biblioteca_digital/capitulos/368-5154rce.pdf

Samaniego, V., Sánchez, R., (2001). Las concepciones del cuerpo y su influencia en el currículum de la Educación Física. Revista digital. Recuperado de http://www.efdeportes.com/efd33a/cuerpo.htm

Tusquets, P., (2011). Culto al cuerpo y sus peligros. Recuperado de 
IMAGINARIOS SOCIALES FRENTE A LA CORPORALIDAD

colegiovaldeserra.eu/wordpress/PI/.../proyecto-culto-al-cuerpo-y-sus-peligros.pdf 
IMAGINARIOS SOCIALES FRENTE A LA CORPORALIDAD

Anexos 


\section{Anexo A. Asentimiento Informado Estudiantes}

Yo

cuento con el consentimiento de tus padres y puedes hablar con ellos en caso de tener dudas frente a tu participación en la investigación. A continuación te daré a conocer algunos de los aspectos de la investigación.

Este estudio pretende conocer desde las voces de los actores: docentes, estudiantes y directivos, los imaginarios y prácticas relacionados con la actividad física, la educación física y el cuerpo para mejorar la salud y calidad de vida de niños y adolescentes.

Por esta razón es necesario reconocer lo que sabes frente al tema, para luego construir con la ayuda de todos un programa que incluya a docentes, estudiantes e instituciones de educación básica, para mejorar la práctica de Actividad Física (AF) como herramienta de en la clase de Educación Física.

Con el fin de recoger esta información participarás en unos grupos que tiene como finalidad conversar acerca de la actividad física, la educación física y el cuerpo, y como se práctica en la escuela (grupos focales). Si alguna pregunta del grupo focal es incómoda, no tienen por qué contestar si no lo desean. Es importante que conozcas que tu participación no tiene ningún riesgo sobre tu cuerpo.

La información que recolectamos para este proyecto de investigación se mantendrá de manera confidencial. La información recolectada por la investigación será aislada y solo los investigadores podrán verla. A la información se le asignará un número de identificación en vez de tu nombre. Solamente los investigadores sabrán el vínculo de ese número con el nombre y la información se mantendrá guardada bajo seguridad. No se compartirá la información ni se le dará a nadie excepto al equipo de investigación y personal a cargo de la sistematización.

Con el fin de proteger su información, la investigadora principal: Diana Camargo Rojas, investigadora de la Facultad de Cultura física, Deporte y Recreación de la Universidad Santo Tomás, mantendrán protegido su registro. Sólo los miembros del equipo de investigación tendrán acceso a la información. Para mayor información podrá comunicarse con la Dra Diana Camargo Rojas al celular 3166226239, correo electrónico: diana.camargo@usantotomas.edu.co. 


\section{Anexo B. Formato de Asentimiento Estudiantes}

Yo

"Sé que puedo elegir participar en la investigación o no hacerlo. Reconozco que mis padres conocen del procedimiento que se realizará y de mi participación en esta investigación o intervención. Sé que puedo retirarme cuando quiera. He leído esta información (o se me ha leído la información) y la entiendo. Me han respondido las preguntas y sé que puedo hacer preguntas más tarde si las tengo. Entiendo que cualquier cambio se discutirá conmigo. Acepto participar en la investigación". Si elegiste ser parte de esta investigación, también te daré una copia de esta información para ti. Puedes pedir a tus padres que lo examinen si quieres.

Solo si el niño/a asiente:

Nombre del niño/a

Firma del niño/a:

Teléfono:

Dirección:

Fecha:

Día/mes/año

O "Yo no deseo participar en la investigación y no he firmado el asentimiento que sigue". (iniciales del niño/menor)

Firma de Testigo del procedimiento de asentimiento: 


\section{Anexo C. Formato de Asentimiento para Padres de Familia}

El presente estudio es propuesto por un equipo de investigadores de la Universidad Santo Tomás, quienes buscan interpretar los imaginarios sociales que se relacionan con la manera como se lleva a la práctica y se comprende el concepto de la Actividad Física y el cuerpo, como herramientas de la Educación Física en Colegios Distritales de la Ciudad de Bogotá. Le vamos a dar información e invitar a usted y a su hijo/hija a que participe en esta investigación. Puede que haya algunas palabras que no entienda. Por favor pídame parar según avanzamos en la información y tomaremos tiempo para explicarlas. Si usted tiene preguntas después, puede realizarlas al equipo de investigación.

\section{Propósito}

El estudio tiene la finalidad de comprender desde las voces de los estudiantes, los imaginarios y prácticas relacionados con la actividad física, la educación física y el cuerpo, que presentan los sujetos y las instituciones, al reconocer la actividad física como una herramienta fundamental para la prevención de enfermedades no transmisibles y para mejorar la salud y calidad de vida de niños y adolescentes.

En la actualidad se presenta una problemática en los niños y niñas de Colombia relacionada con la obesidad y otras enfermedades ocasionadas por la poca actividad física que realizan los niños por el tiempo en el cual están sentados, enfermedades que se pueden complicar en la adultez; es por esto que es necesario reconocer los saberes de la población acerca del tema, para luego implementar un programa que incluya docentes, estudiantes e instituciones de educación básica, y que comprenda la Actividad Física (AF) como herramienta de la Educación Física para mejorar las condiciones de salud y de interacción social en entornos de violencia, para los cuidados preventivos del cuerpo y de la salud.

\section{Tipo de Intervención de Investigación}

En el marco del proyecto se realizarán entrevistas y grupos focales con los padres de familia, docentes, estudiantes y directivos de las instituciones.

\section{Riesgos}

No hay ningún riesgo por participar en este estudio. Si alguna pregunta de la entrevista o del grupo focal es incómoda para usted o para los niños/niñas, no tienen por qué contestar si no lo desean.

\section{Beneficios}

Aunque no reciban ningún beneficio directo, esperamos que los niños, docentes e instituciones, así como la sociedad en general puedan beneficiarse con los resultados de la investigación. 


\section{Selección de Participantes}

Le estamos invitando a tomar parte de esta investigación porque es importante indagar acerca de los imaginarios y prácticas de todos los actores acerca de la actividad física, así como implementar y evaluar programas que permitan prevenir las enfermedades no transmisibles, mejorar procesos de interacción social y convivencia, así como el reconocimiento del cuerpo, la salud y calidad de vida de los niños. Ya que usted y su hijo/a son parte de la comunidad académica de los colegios en los cuales se realizará el estudio, le preguntamos si usted permitiría que participe su hijo/a y si usted está de acuerdo con participar.

\section{Participación Voluntaria}

Su decisión de que su niño/a y usted participe en este estudio es completamente voluntaria. Es su decisión el que su niño/a y usted participe o no. Si usted elige no consentir, todos los servicios que usted y su niño/a reciban en el Colegio continuarán y nada cambiara. Usted puede también cambiar su decisión más tarde y dejar de participar, aun cuando haya aceptado previamente y continuarán los servicios que usted y/o su niño/a reciban en el colegio.

\section{Confidencialidad}

La información que recolectamos para este proyecto de investigación se mantendrá confidencial. La información acerca de usted y de su su niño/a, recolectada por la investigación será aislada y solo los investigadores podrán verla. Cualquier información sobre usted y su niño/a se le asignará un número de identificación en vez de su nombre. Solamente los investigadores sabrán el vínculo de ese número con el nombre y la información se mantendrá guardada bajo seguridad. No se compartirá la información ni se le dará a nadie excepto al equipo de investigación y personal a cargo de la sistematización. 


\section{Anexo D. Formulario de consentimiento Padres de Familia}

He leído la información proporcionada, o me ha sido leída. He tenido la oportunidad de preguntar dudas sobre ello y se me ha respondido satisfactoriamente. Consiento voluntariamente mi participación y la de mi niño/a participe en este estudio y entiendo que tengo el derecho de retirarme del estudio, así como retirar a mi niño/a en cualquier momento sin que afecte de ninguna forma el servicio educativo y a mí niño/a.

Nombre del Participante

Nombre del Padre/Madre o Apoderado

Firma del Padre/Madre o Apoderado

Fecha ( Día/mes/año)

\begin{tabular}{|l|l|}
\hline Testigos : & \\
$\begin{array}{l}\text { Nombres y apellidos } \\
\begin{array}{l}\text { Dirección y relación con el sujeto de } \\
\text { investigación }\end{array}\end{array}$ & $\begin{array}{l}\text { Nombres y apellidos } \\
\text { Dirección y relación con el sujeto de } \\
\text { investigación }\end{array}$ \\
\hline Firma & \begin{tabular}{l} 
Firma \\
\hline
\end{tabular}
\end{tabular}

Si el sujeto de investigación no sabe firmar imprimirá su huella digital y a su nombre firmará otra persona que él designe.

Se ha proporcionado una copia de este documento de Consentimiento Informado al padre/madre o apoderado del participante (inicial del investigador/asistente) 


\section{Anexo E. Complemento Asentimiento Informado}

Yo, con $\mathrm{CC}$ de

\begin{tabular}{cccc} 
certifico que & el & y nun \\
\hline
\end{tabular}
niño(a)/menor con nombre número de identificación verbal el propósito, riesgos, beneficios, la participación voluntaria y la confidencialidad de la investigación IMAGINARIOS SOCIALES FRENTE A LA CORPORALIDAD DE ESTUDIANTES DE GRADO DECIMO DEL COLEGIO LEONARDO POSADA PEDRAZA IED LOCALIDAD BOSA.; 2. Afirma conocer la posibilidad de desvinculación de la investigación en el momento de que lo considere; 3. Ratifica de manera verbal y escrita su deseo de participar en la investigación.

Firma

Nombre del Testigo:

Identificación del Testigo:

Fecha: 


\section{Anexo F. Cuestionario Entrevista Corporalidad}

\section{RELACION SUBJETIVA CON EL CUERPO}

Imagen corporal IM

1. ¿Qué cuidados tiene usted en relación con su cuerpo?

2. ¿Cómo se siente con su cuerpo?

3. Al mirarse frente al espejo ¿que ve usted?

4. ¿Cómo cree que ven su cuerpo los demás?

5. ¿Cómo crees que los demás ven tu cuerpo?

6. ¿Qué tan importante es para ustedes la opinión que los demás tiene con respecto a su corporalidad?

\section{RELACION CUERPO MOVIMIENTO}

7. ¿Qué funciones cumple el cuerpo en la cotidianidad?

8. ¿Cómo siente o percibe su cuerpo durante la práctica de la actividad física?

9. ¿Qué beneficios tiene la actividad física en su cuerpo?

10. ¿Considera necesario mantener una buena imagen corporal?

11. ¿Cómo se maneja ese aspecto en su vida?

12. ¿Qué entiende usted por cuerpo y por corporalidad? 
IMAGINARIOS SOCIALES FRENTE A LA CORPORALIDAD 


\section{Anexo G. Cuestionario de lectura de necesidades}

\section{ASPECTO AFECTO Y PROTECCIÓN}

1. Como está conformado su grupo familiar?

\begin{tabular}{l}
$\square$ Vivo con mamá, papá y hermanos(as) \\
\hline Vivo con uno de mis padres y hermanos. \\
Vivo con sólo uno de mis padres. \\
\hline Vivo con otros familiares \\
$\square$ Otro, Cuál:
\end{tabular}

2. Como son las relaciones afectivas con su grupo familiar?
Muy Buenas
$\square$ Buenas
$\square$ Regulares
Malas

3. Escoja cuál o cuáles de las siguientes situaciones se presentan en su casa: (marque una $\mathrm{X}$ en el cuadro anterior al enunciado correspondiente)

\begin{tabular}{|l|l|}
\hline & Maltrato Físico \\
\hline & Maltrato Verbal \\
\hline & Discusiones frecuentes - peleas \\
\hline & Problemas de Alcohol. \\
\hline
\end{tabular}

\begin{tabular}{|l|l|}
\hline & Desplazamiento Social \\
\hline & Intervención de Bienestar Familiar \\
\hline & Problemas de Drogadicción \\
\hline & Ninguna. \\
\hline
\end{tabular}

4. Como se distribuyen las obligaciones y responsabilidades en el hogar? (marque una $\mathrm{X}$ en el cuadro anterior al enunciado correspondiente)

\begin{tabular}{|l|l|}
\hline & Ambos padres trabajan. \\
\hline & Sólo trabaja el papá \\
\hline & Sólo trabaja la mamá \\
\hline & Ninguno de los dos trabaja \\
\hline
\end{tabular}

\begin{tabular}{|l|l|}
\hline & $\begin{array}{l}\text { Las labores domésticas sólo las } \\
\text { hace la mamá }\end{array}$ \\
\hline $\begin{array}{l}\text { Las labores domésticas sólo las } \\
\text { hace el papá }\end{array}$ \\
\hline $\begin{array}{l}\text { En las labores domésticas } \\
\text { colaboramos todos. }\end{array}$ \\
\hline $\begin{array}{l}\text { Se contrata a alguien para hacer } \\
\text { las labores domésticas }\end{array}$ \\
\hline
\end{tabular}


IMAGINARIOS SOCIALES FRENTE A LA CORPORALIDAD

5. Describa como son sus relaciones con sus amigos y compañeros?

Muy Amistosas $\square$ Amistosas. $\square$ Poco Amistosas $\square$ Nada Amistosas

\section{ASPECTO DE SUBSISTENCIA.}

1. En un día normal ¿Cómo considera que usted se alimenta?

$\square$ Muy Bien $\square$ Bien $\square$ Regular $\square$ Mal

2. Cuántas Comidas consumes al día?

$\square$ Las Tres Básicas $\square$ Más de las tres básicas $\square$ Menos de las tres básicas

3. ¿Qué alimentos componen cada una de sus comidas básicas? (marque $\mathrm{X}$ en los que consumes)

\begin{tabular}{l}
$\square$ Harinas \\
\hline$\square$ Verduras \\
\hline Carnes \\
$\square$ Lácteos \\
$\square$ Frutas
\end{tabular}

4. ¿Maneja algún tipo de dieta personal o por prescripción médica?

No Si Sí su respuesta es afirmativa conteste el Por Qué?

\section{ASPECTO DE SALUD.}

1. ¿Su hogar cuenta con cuáles servicios públicos básicos? (marque con una X los servicios que tiene en casa)

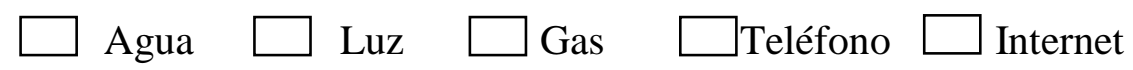

2. ¿Con que frecuencia asiste a controles médicos?

$\square$ De uno a tres meses $\square$ De tres a seis meses $\square$ Una vez al año Sólo cuando me siento enfermo

3. ¿Cómo considera usted que ha sido su salud en el último año?

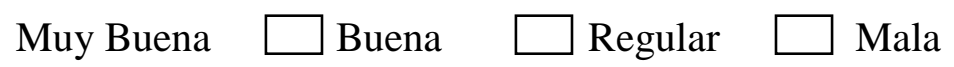


IMAGINARIOS SOCIALES FRENTE A LA CORPORALIDAD

4. ¿Cuál fue el motivo por el que asistió al médico la última vez?

Enfermedad $\square$ Control Médico $\square$ Accidente $\square$ No me acuerdo

Y hace cuánto fue:

$\square$ Menos de un mes $\square$ De uno a tres meses $\quad \square$ Hace más de seis meses

5. En su familia (padres, abuelos, hermanos, tíos, etc.) ¿Cuáles son las enfermedades más frecuentes?

\begin{tabular}{ll}
$\square$ & Enfermedades Cardiacas \\
\hline$\square$ Problemas de Cáncer & $\square$ Diabetes \\
Hipertensión Arterial & $\square$ Obesidad
\end{tabular}

\section{ASPECTO DE ACTIVIDAD FÍSICA}

1. Fuera de la clase de educación física ¿qué otro tipo de actividad física realiza y con qué frecuencia?

2. ¿En los fines de semana y periodos vacacionales, realiza actividad física?

Si $\square$ No Cuál o Cuáles:

3. ¿En dónde vive, es decir, en su entorno existen espacios y/o elementos que facilitan o limitan el que usted realice actividad física?

$\square$ Si $\square$ No

4. ¿Considera usted que tiene las habilidades para realizar cualquier actividad física?

Si $\square$ No Por qué:

5. ¿Comparte con su familia las actividades físicas que usted realiza en su tiempo libre?

$\square$ Siempre $\square$ En ocasiones $\square$ Casi Nunca $\square$ Nunca 


\section{Anexo G. Test de Autoevaluación Fantástico}

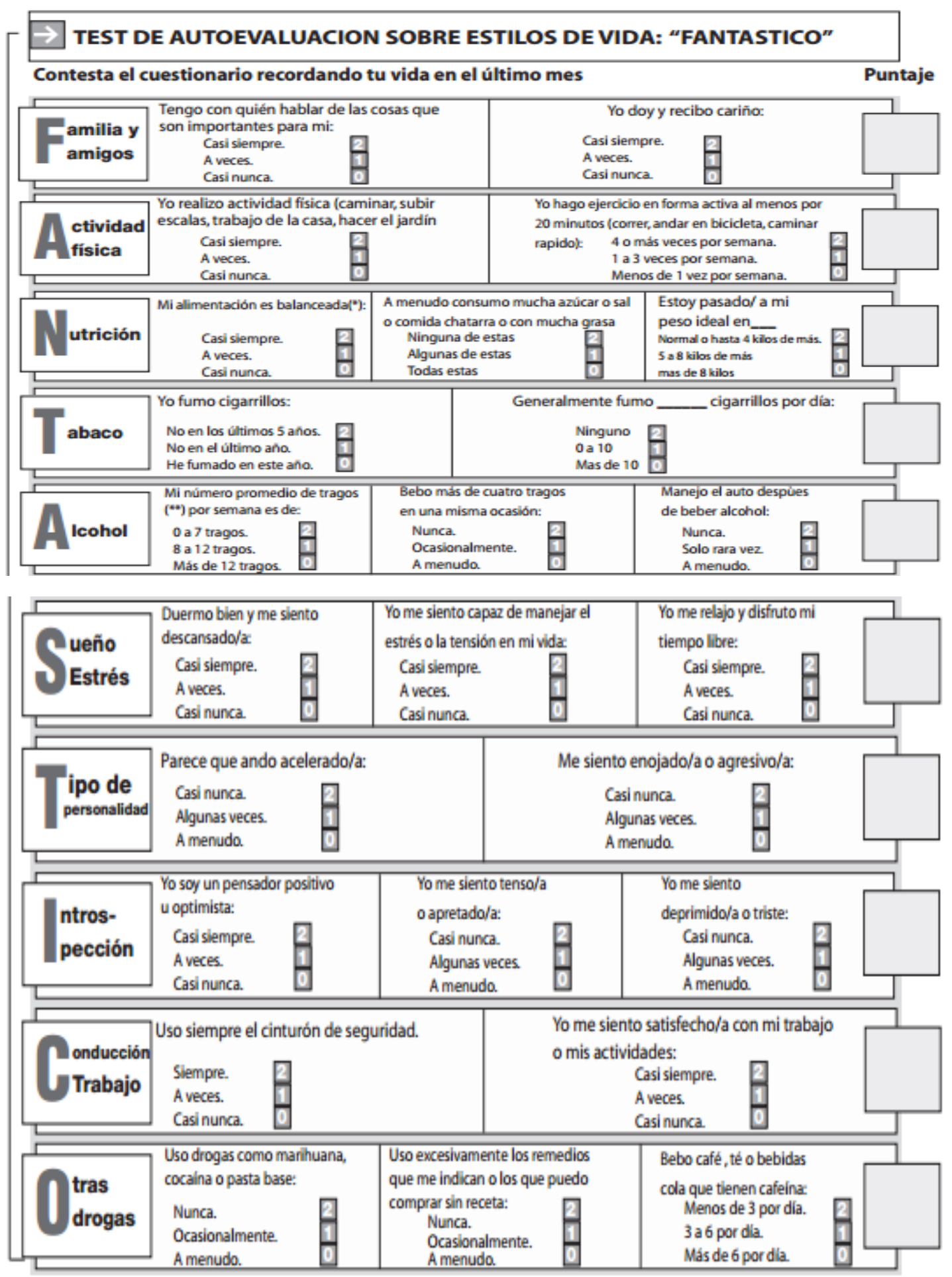

Adaptación autorizada de Mcrnaster University, Ontario, Canada.

"Do you have a fantastic lifestyle?. Convenio Promoción de la Salud Cansda - Chile

Fuente: Ministerio de Salud Departamentos de Epidemiologia y Promoción de la salud - Consejo Nacional VIDA CHILE 


\section{Anexo H. Tabla de Frecuencia Absoluta}

\begin{tabular}{|c|c|c|c|c|c|c|c|c|}
\hline & $\mathbf{A}$ & B & $\mathbf{C}$ & D & $\mathbf{E}$ & $\mathbf{F}$ & $\mathbf{G}$ & Total \\
\hline 1 & 17 & 7 & 2 & 2 & 2 & & & 30 \\
\hline 2 & 6 & 7 & 7 & 5 & 3 & 2 & 0 & 30 \\
\hline 3 & 10 & 7 & 10 & 2 & & & & 29 \\
\hline 4 & 5 & 6 & 11 & 8 & & & & 30 \\
\hline 5 & 5 & 6 & 11 & 8 & & & & 30 \\
\hline 6 & 5 & 6 & 11 & 8 & & & & 30 \\
\hline 7 & 5 & 6 & 11 & 8 & & & & 30 \\
\hline 8 & 10 & 3 & 2 & 1 & 4 & 10 & & 30 \\
\hline 9 & 10 & 3 & 2 & 1 & 4 & 10 & & 30 \\
\hline 10 & 10 & 20 & & & & & & 30 \\
\hline 11 & 10 & 20 & & & & & & 30 \\
\hline 12 & 10 & 20 & & & & & & 30 \\
\hline 13 & 10 & 3 & 15 & 2 & & & & 30 \\
\hline 14 & 10 & 3 & 15 & 2 & & & & 30 \\
\hline 15 & 10 & 3 & 15 & 2 & & & & 30 \\
\hline 16 & 10 & 3 & 15 & 2 & & & & 30 \\
\hline 17 & 2 & 5 & 9 & 7 & 2 & 5 & & 30 \\
\hline
\end{tabular}


IMAGINARIOS SOCIALES FRENTE A LA CORPORALIDAD

\begin{tabular}{llllll}
\hline 19 & & & & & 0 \\
\hline 20 & 10 & 3 & 2 & 15 & 30 \\
\hline 21 & 10 & 20 & & & 30 \\
\hline 22 & 10 & 20 & & & 30 \\
\hline 23 & 10 & 3 & 14 & 3 & 30 \\
\hline
\end{tabular}




\section{Anexo I. Tabla de Frecuencia Absoluta en Porcentaje}

\begin{tabular}{|c|c|c|c|c|c|c|c|c|}
\hline ¿? & $\mathbf{A}$ & B & C & D & $\mathbf{E}$ & $\mathbf{F}$ & G & Total \\
\hline 1 & $57 \%$ & $23 \%$ & $7 \%$ & $7 \%$ & $7 \%$ & $0 \%$ & $0 \%$ & $100 \%$ \\
\hline 2 & $20 \%$ & $23 \%$ & $23 \%$ & $17 \%$ & $10 \%$ & $7 \%$ & $0 \%$ & $100 \%$ \\
\hline 3 & $33 \%$ & $23 \%$ & $33 \%$ & $7 \%$ & $0 \%$ & $0 \%$ & $0 \%$ & $97 \%$ \\
\hline 4 & $17 \%$ & $20 \%$ & $37 \%$ & $27 \%$ & $0 \%$ & $0 \%$ & $0 \%$ & $100 \%$ \\
\hline 5 & $17 \%$ & $20 \%$ & $37 \%$ & $27 \%$ & $0 \%$ & $0 \%$ & $0 \%$ & $100 \%$ \\
\hline 6 & $17 \%$ & $20 \%$ & $37 \%$ & $27 \%$ & $0 \%$ & $0 \%$ & $0 \%$ & $100 \%$ \\
\hline 7 & $17 \%$ & $20 \%$ & $37 \%$ & $27 \%$ & $0 \%$ & $0 \%$ & $0 \%$ & $100 \%$ \\
\hline 8 & $33 \%$ & $10 \%$ & $7 \%$ & $3 \%$ & $13 \%$ & $33 \%$ & $0 \%$ & $100 \%$ \\
\hline 9 & $33 \%$ & $10 \%$ & $7 \%$ & $3 \%$ & $13 \%$ & $33 \%$ & $0 \%$ & $100 \%$ \\
\hline 10 & $33 \%$ & $67 \%$ & $0 \%$ & $0 \%$ & $0 \%$ & $0 \%$ & $0 \%$ & $100 \%$ \\
\hline 11 & $33 \%$ & $67 \%$ & $0 \%$ & $0 \%$ & $0 \%$ & $0 \%$ & $0 \%$ & $100 \%$ \\
\hline 12 & $33 \%$ & $67 \%$ & $0 \%$ & $0 \%$ & $0 \%$ & $0 \%$ & $0 \%$ & $100 \%$ \\
\hline 13 & $33 \%$ & $10 \%$ & $50 \%$ & $7 \%$ & $0 \%$ & $0 \%$ & $0 \%$ & $100 \%$ \\
\hline 14 & $33 \%$ & $10 \%$ & $50 \%$ & $7 \%$ & $0 \%$ & $0 \%$ & $0 \%$ & $100 \%$ \\
\hline 15 & $33 \%$ & $10 \%$ & $50 \%$ & $7 \%$ & $0 \%$ & $0 \%$ & $0 \%$ & $100 \%$ \\
\hline 16 & $33 \%$ & $10 \%$ & $50 \%$ & $7 \%$ & $0 \%$ & $0 \%$ & $0 \%$ & $100 \%$ \\
\hline 17 & $7 \%$ & $17 \%$ & $30 \%$ & $23 \%$ & $7 \%$ & $17 \%$ & $0 \%$ & $100 \%$ \\
\hline 18 & $0 \%$ & $0 \%$ & $0 \%$ & $0 \%$ & $0 \%$ & $0 \%$ & $0 \%$ & $0 \%$ \\
\hline
\end{tabular}


IMAGINARIOS SOCIALES FRENTE A LA CORPORALIDAD

\begin{tabular}{lcccccccc}
\hline 19 & $0 \%$ & $0 \%$ & $0 \%$ & $0 \%$ & $0 \%$ & $0 \%$ & $0 \%$ & $0 \%$ \\
\hline 20 & $33 \%$ & $10 \%$ & $7 \%$ & $50 \%$ & $0 \%$ & $0 \%$ & $0 \%$ & $100 \%$ \\
\hline 21 & $33 \%$ & $67 \%$ & $0 \%$ & $0 \%$ & $0 \%$ & $0 \%$ & $0 \%$ & $100 \%$ \\
\hline 22 & $33 \%$ & $67 \%$ & $0 \%$ & $0 \%$ & $0 \%$ & $0 \%$ & $0 \%$ & $100 \%$ \\
\hline 23 & $33 \%$ & $10 \%$ & $47 \%$ & $10 \%$ & $0 \%$ & $0 \%$ & $0 \%$ & $100 \%$ \\
\hline
\end{tabular}

